\title{
Small-sized Trochammina assemblages in deep-water Eocene flysch deposits (Outer Carpathians, Poland) and their palaeoecological implications
}

\author{
ANNA WAŚKOWSKA \\ AGH University of Science and Technology, Faculty of Geology, Geophysics and Environmental Protection, \\ Department of General Geology and Geotourism, Mickiewicza Ave. 30, 30-059 Kraków, Poland \\ (e-mail: waskowsk@agh.edu.pl)
}

\begin{abstract}
The global climate change in the early Eocene contributed significantly to the turnover of benthic foraminifera. A major extinction within agglutinated and calcareous forms and the occurrence of opportunistic assemblages resulted. The Trochammina material described here belongs to these post-crisis assemblages. Foraminiferal assemblages with numerous Trochammina species are identified within deep-water Eocene deposits of the Polish part of the Outer Carpathians. Trochammina reach up to $80 \%$ of the assemblages, the remainder consists of cosmopolitan agglutinated foraminifera, mainly Bathysiphon, Recurvoides, Paratrochamminoides and Trochamminoides. The low biodiversity (average number of species 24, of genera 15 ) and the presence of dwarf forms are the main characteristics of the assemblages. These assemblages occur predominantly in shales with numerous organic traces (lower Hieroglyphic beds), deposited in the Silesian Basin (Outer Carpathians) which was on the northern margin of the western Tethys Ocean during the early Eocene (Ypresian, c. 50Ma). The Trochammina biofacies developed in the Silesian Basin after the PaleoceneEocene Thermal Maximum crisis, and is dominated by opportunistic forms, mainly represented by mobile epifauna and shallow-water infauna, interpreted as a recolonizing assemblage in a low energy environment.
\end{abstract}

KEYWORDS: agglutinated foraminifera, Trochammina, deep water, palaeoecology, biostratigraphy, early Eocene, Outer Carpathians

\section{INTRODUCTION}

Deep-water benthic foraminifera commonly inhabit environments that are dominated by 'flysch' sedimentation, a special type of environment where benthic foraminifera colonize the sea floor at depths of up to several thousand of metres, in radically changing conditions of oxygen and nutrient supply (e.g. Miller \& Lohmann, 1982; Schönfeld, 2002; Smith \& Gallagher, 2003; Ortiz et al. 2011). Water depth affects water column pressure and bottom temperature which are crucial to the benthos, as these parameters limit the development of calcareous-shelled fauna (e.g. Funnell, 1967; Schnitker \& Tjalsma, 1980; Corliss \& Honjo, 1981; Olszewska, 1981, 1984; van Morkhoven et al., 1986; Tjalsma \& Lohmann, 1983; Waśkowska-Oliwa, 2005). The delivery of oxygen and food is dependent on the supply of water and sediment to the basin floor. In deep-sea environments this is controlled primarily by the amount and intensity of gravity currents. Turbidites have a strong influence on the benthic foraminiferal occurrence and distribution (Ortiz et al., 2011). However, these currents can bring materials needed by benthic organisms, and/or may cause a threat for the foraminiferal population and may bury it. The palaeontological record in flysch deposits can be variable, especially in high-energy environments as foraminifera generally prefer low-energy environments, and muddy rather than sandy substrates. Assemblages that are associated with thicker mudstone series are good environmental indicators because they mostly represent the autochthonous assemblage that was living on the sea floor during times when gravity currents had no significant impact. The lower parts of the Hieroglyphic beds represent such a sedimentary setting. Assemblages with a number of small-sized Trochammina have previously been identified within these deposits (Waśkowska, 2012).

Assemblages dominated by one or a few species/genera are well known from the flysch depositional environments of the
Outer Carpathians. The increased abundance of, for example, Glomospira, Nothia, Bathysiphon, Paratrochamminoides, Reophax, Recurvoides and Praesphaerammina is well known in Eocene deep-water deposits (e.g. Geroch, 1960; Geroch et al. 1967; Jurkiewicz, 1967; Bubik, 1995b; Bąk et al. 1997; Olszewska, 1997; Waśkowska-Oliwa, 2000; Bąk, 2004; Kender et al., 2005; Waśkowska, 2011a). The appearance of such assemblages in deep-water conditions is associated with specific changes in the environment, often of regional or wider significance. Some of these foraminiferal acmes are characteristic of specific time intervals, and are used successfully as stratigraphic indicators in the Carpathian basins and further afield in the western Tethys (Kaminski, 2005).

\section{GEOLOGICAL BACKGROUND}

The Outer Carpathians have a nappe structure which was developed in the Miocene. Micropaleontological research was carried out on Eocene deposits belonging to the Silesian Nappe (Fig. 1a) including the informal subdivision named as Hieroglyphic beds. A formal lithostratigraphy for the studied region has yet to be defined. The deposits analysed in this work are from the Kamesznica region (Janoska section, Beskid Ślaski Range) and the Szczyrzyc region (Krzesławice section, Beskid Wyspowy Range) (Fig. 1b, c). Hieroglyphic beds are represented there by thin-bedded flysch shale-sandstone deposits (Burtan, 1974, 1978; Chodyń \& Waśkowska-Oliwa, 2006; Waśkowska-Oliwa et al. 2008; Doktor et al., 2010). Mudstones are dominant, forming sequences of beds of variable thicknesses from several centimetres to tens of metres, grey, green and bluish in colour. Thin intercalations of variegated shales are observed locally in thicker complexes. The intercalated sandstones are usually siliceous, thin-bedded and fine-grained. Their characteristic feature, which gives the name to the unit, is 


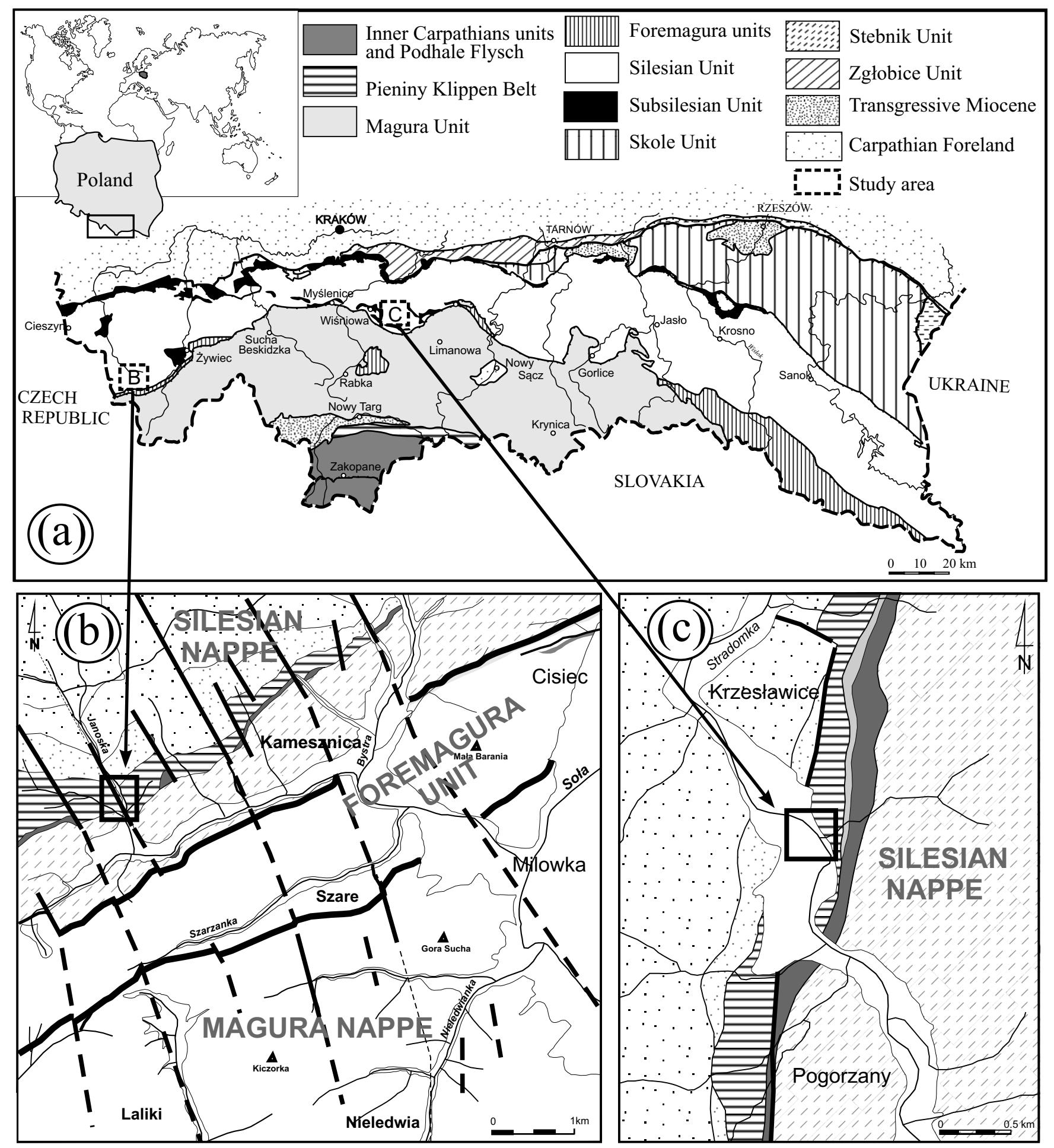

SILESIAN NAPPE

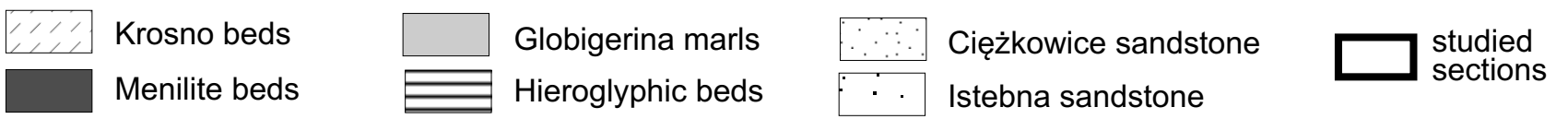

Fig. 1. (a) Geological sketch-maps of study areas on the background tectonic map of the Polish Carpathians: (b) Kamesznica area, after Burtan et al. (1956, modified); (c) Krzesławice area, after Chodyń \& Waśkowska-Oliwa (2006, modified). 
the presence of numerous sedimentary features reminiscent of hieroglyphics. The sampled sections belong to the Hieroglyphic beds where sandstone beds are missing or represent only a minor component of the lithology (Fig. 3).

The studied sediments were deposited in the Outer Carpathians basin, which was a part of the Tethys Ocean and had the features of a deep-sea basin, dominated by flysch-type sedimentation. Its range and inner configuration changed over time. In the Late Cretaceous, interbasinal elevations subdivided the basinal area into smaller sub-basins, one of which was the Silesian Basin (Fig. 2). The Early Paleogene was a time of tectonic reorganization, which occurred as a result of the subsidence of some previously elevated structures (Golonka et al., 2006, 2008, 2011; Golonka, 2011 and papers cited therein). The Miocene tectonic movements that formed the present architecture of the Outer Carpathians led to the uplift and emergence of accumulated deposits in the Carpathian basins and their transformation into nappes. The nappes were superimposed on to one another, and the separation between them more or less coincides with the formation of Late CretaceousEarly Paleogene basins (Golonka \& Waśkowska-Oliwa, 2007).

\section{METHODS AND MATERIALS \\ Lithostratigraphic position}

The small-sized Trochammina assemblages are identified in deposits of the Beskid Śląski and Beskid Wyspowy ranges in the Silesian Nappe. In both analysed profiles, spaced $100 \mathrm{~km}$ apart, the Trochammina assemblages occur in the lower part of the stratigraphic section, overlying the strongly reduced Ciężkowice sandstone (Fig. 3). The lithology of the lower part of the Hieroglyphic beds is similar in the analysed profiles, even though they were located at widely separated areas during the early Eocene. The lower part of the Hieroglyphic beds is developed as a mudstone facies, with an almost total lack of sandstones. The highly bioturbated deposits are grey and green, and contain authogenic pyrite and a large admixture of muscovite. In both sections, intercalations of variegated mudstones are present, which are of smaller proportion than in typical hieroglyphic facies; they are accessory and of limited thickness. Intercalations of the variegated mudstones are concentrated in the lower part of Hieroglyphic beds. The characteristic feature of the western section, the Janoska profile, is the common occurrence of sideritic nodules ranging in size from a few centimetres to tens of centimetres in length, which are not found in Krzesławice. Above the sequence of grey mudstones with numerous Trochammina, the lithology of the Hieroglyphic beds changes slightly, with an increase in parallel and/or wavy laminated thinbedded sandstones with quartz and muscovite.

\section{Lithology}

Assemblages with small-sized Trochammina have been identified in the sequence $(50-100 \mathrm{~m})$ of green-grey mudstone (Fig. 3). The proportion of carbonate is estimated to be on average $1-3 \mathrm{~g} \mathrm{~kg}^{-1}$ and the mudstones are characterized by very low TOC, between 0.03 and $0.04 \%$. The mudstones are heavily bioturbated. A few variegated shale intercalations up to tens of centimetres in thickness occur within the mudstones. Very fine-grained, thin-bedded sandstones are rare, and are found only in the Janoska section. After sample processing, the sand-sized fraction of the residue was found to be relatively small, mostly represented by foraminifera with a dominance of thick- and medium-grained agglutinated forms. The characteristic feature of the mudstone is the increased abundance of muscovite, which occurs frequently as thin petallike crystal fragments. Muscovite is very common in the flysch sediments; it belongs to a group of mica that is resistant to chemical weathering, and is an allogenic component. Foraminifera, especially the coarse-grained epifaunal forms (i.e. Bathysiphon or Trochammina), have muscovite clasts incorporated into their tests (Plate 1). Another feature of this deposit is the presence of numerous pyrite grains. They occur most often as authogenic regular crystals of isometric shape and various sizes, and are also found incorporated into agglutinated foraminifera tests.

\section{Methodology}

The 30 studied samples were collected from outcrops in the banks of two Carpathian streams: Janoska and Stradomka (Fig. 1b, c). The weight of each sample was about $1 \mathrm{~kg}$. The material was prepared according to a standard micropaleontological preparation procedure, including maceration in a saturated Glauber's salt solution, and washing over a $63 \mu \mathrm{m}$ sieve. Foraminifera from the residues were picked quantitatively and photographically documented using a binocular microscope and scanning electron microscope. All foraminifera were picked from each sample, except samples with a large number of specimens. Such samples were divided into equalsized random splits and foraminifera were picked from one part of the residue. The number of foraminifera in the whole sample was estimated on the basis of the random split. The abundance of foraminifera was very varied, from 300 to over 3100 specimens per sample from the Krzesławice section, and from 700 to over 10000 specimens per sample in the Janoska section. Some foraminifera, such as tubular taxa (e.g. Bathysiphon, Psammosiphonella, Rhizammina) and uniserial multichambered taxa (e.g. Reophax, Subreophax, Hormosina), were preserved only as fragments, which were counted as individual specimens. Trochammina dimensions were measured on specimens from Krzesławice section samples (Table 1). The diameter of rounded-shaped forms or the longer axis in elongated forms were measured using a binocular microscope. A total of 120-300 specimens of Trochammina per sample were measured. Measurements were made on samples in which the amount of Trochammina exceeds 120 specimens.

The samples are housed in the author's collection in the Department of General Geology and Geotourism at the AGH University of Science and Technology in Kraków.

\section{RESULTS \\ Biostratigraphy}

A typical feature of the small-sized Trochammina assemblages is that they are taxonomically poor, with cosmopolitan agglutinated forms which have little biostratigraphical value. Only Saccamminoides carpathicus Geroch, an index taxon for the late Ypresian, occurs irregularly in the sampled sections. This species occurs at Janoska in samples 138/18/07, 135/13/07, 130/8/07, $137 / 17 / 07$ and 129/7/07 (Fig. 3c). At Krzesławice, in sample $71 / 39 / 05$ (variegated shales), in an assemblage with an increased proportion of Trochammina, one specimen was identified as ?Saccamminoides carpathicus Geroch. In the same profile, sample 11/38a/09 (collected about $10 \mathrm{~m}$ below sample 71/39/05) (Fig. 3b), yielded a specimen of Reticulophragmium amplectens (Grzybowski) (Fig. 4). The first appearance of this species in the Carpathians flysch is dated as late Ypresian in age, and it may 

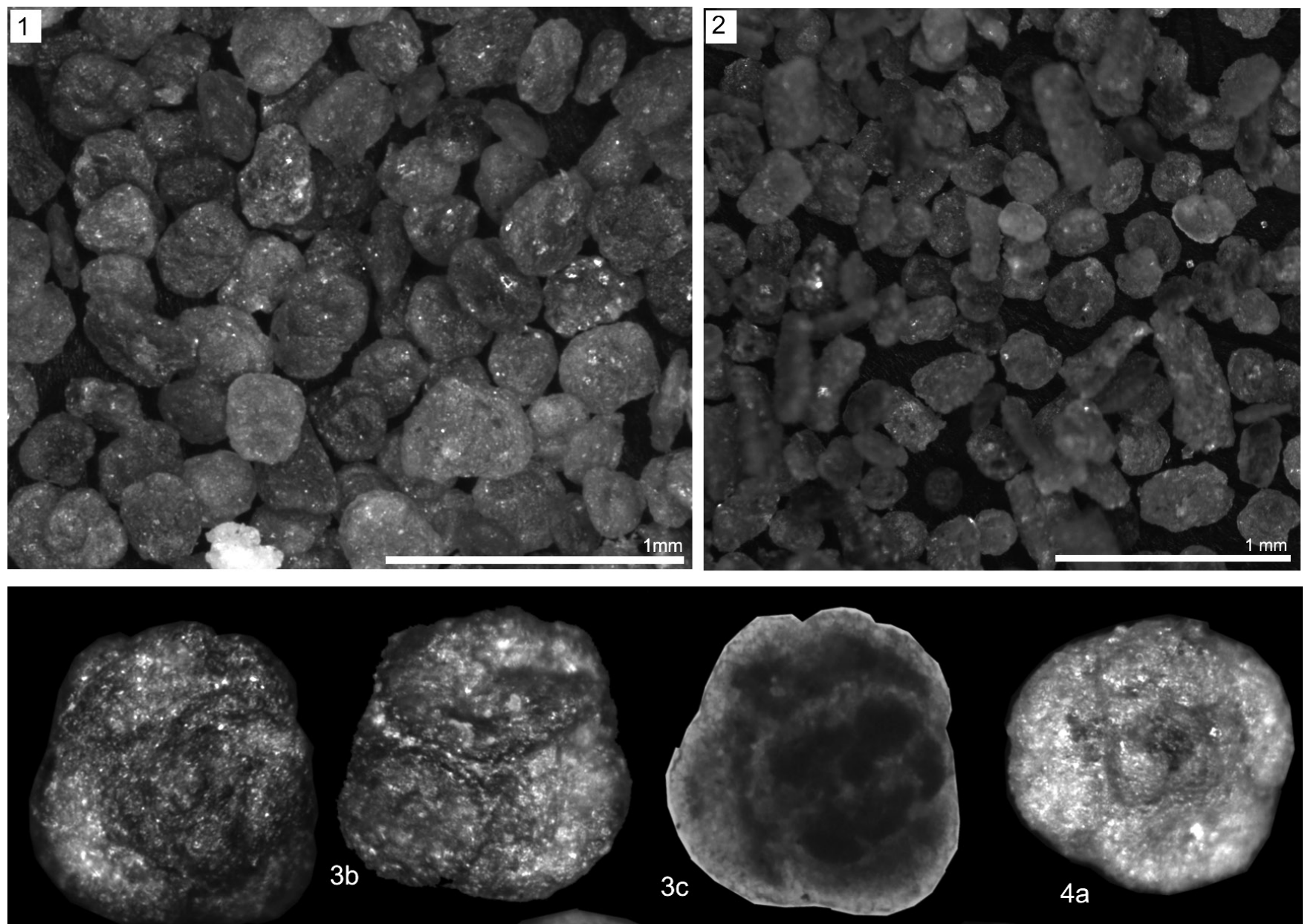

$3 a$
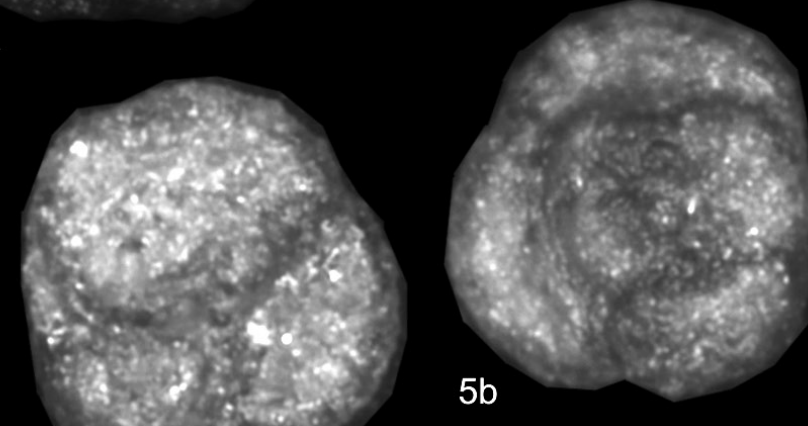

$5 a$

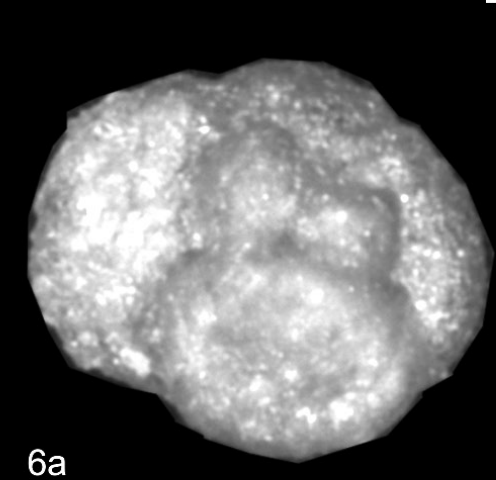

$4 b$
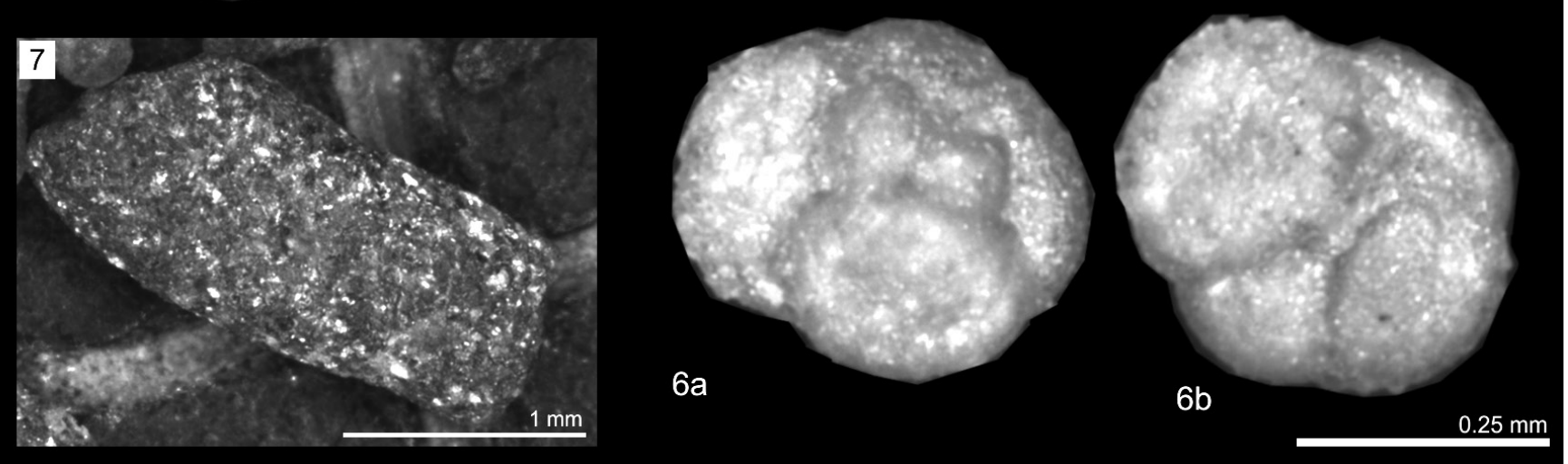
Table 1. Dimensions of Trochammina tests in the Krzesławice section (\%)

\begin{tabular}{|c|c|c|c|c|c|c|c|c|c|}
\hline \multirow[b]{2}{*}{ Sample } & \multicolumn{9}{|c|}{ Diameter (length) of Trochammina specimens (mm) } \\
\hline & $>0.2$ & $0.21-0.25$ & $0.26-0.30$ & $0.31-0.35$ & $0.36-0.40$ & $0.41-0.45$ & $0.46-0.50$ & $<0.50$ & Number of measured specimens \\
\hline $40 / 36 / 5$ & 5.21 & 7.81 & 15.63 & 15.71 & 22.96 & 14.00 & 10.58 & 8.07 & 300 \\
\hline $93 / 63 / / 09$ & 2.75 & 15.17 & 37.93 & 30.00 & 7.93 & 3.79 & 1.03 & 1.37 & 290 \\
\hline $10 / 37 / 06$ & 4.93 & 27.98 & 36.21 & 24.69 & 2.26 & 2.88 & 0.61 & 0.42 & 300 \\
\hline $71 / 39 / 05$ & 7.50 & 25.00 & 22.50 & 27.50 & 12.50 & 3.75 & 0.62 & 0.62 & 300 \\
\hline $93 / 64 / 09$ & - & 16.40 & 33.33 & 31.74 & 13.22 & 3.70 & 1.05 & 0.52 & 200 \\
\hline $41 / 40 / 06$ & 0.93 & 40.18 & 39.25 & 14.95 & 4.67 & - & - & - & 220 \\
\hline $95 / 65 / 09$ & 3.76 & 46.77 & 40.32 & 7.52 & 1.07 & 0.53 & - & - & 200 \\
\hline $90 / 42 / 05$ & - & 21.42 & 17.85 & 25.89 & 6.25 & 24.10 & 1.78 & 2.67 & 120 \\
\hline
\end{tabular}

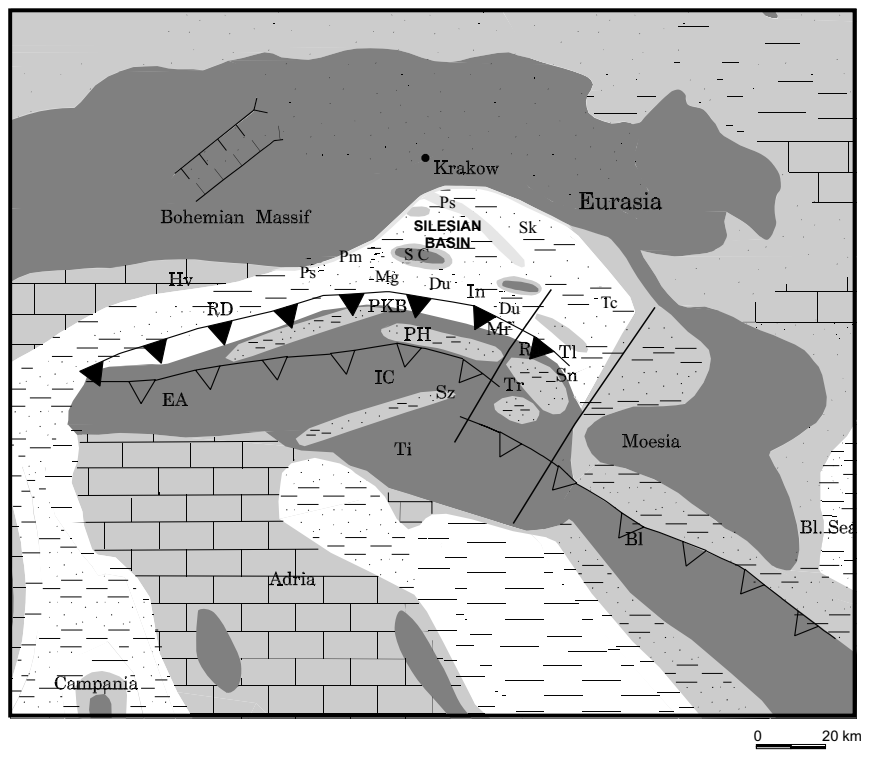

LAND

SHALLOW WATER

DEEP WATER SANDSTONE, SILTSTONE SHALE, CLAY, MUDSTONE LIMESTONE

-- SAND AND SHALE

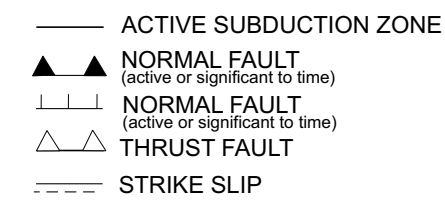

Fig. 2. Palaeogeographical position of the Carpathian Silesian Basin in the Eocene (45 Ma), after Golonka et al. (2006, modified). Abbreviations: B1, Balkan Basin and foldbelt; Du, Dukla Basin; EA, Eastern Alps; Hv, Helvetic shelf; IC, Inner Carpathians; In, Inacovce-Kricevo zone; $\mathrm{Mg}$, Magura Basin; Mr, Marmarosh Massif; PH, Inner Carpathian (Podhale) Basin; PKB, Pieniny Klippen Belt; Pm, Fore-Magura Basin; Ps, SubSilesian Ridge and slope zone; Ra, Rakhiv Basin; RD, Rheno Danubian; SC, Silesian Ridge (Cordillera); Sk, Skole Basin; Sn, Sinaia Basin; Sz, Szolnok Basin; Tc, Tarcau Basin; Ti, Tisa plate; Tl, Teleajen Basin; Tr, Transilvanian Basin. co-occur in a short interval together with Saccamminoides carpathicus (Olszewska et al., 1996; Olszewska, 1997; Kaminski \& Gradstein, 2005; Waśkowska, 2011b). From the deposits with the Trochammina biofacies the following taxa were recognized: Pseudonodosinella elongata (Grzybowski), Eratidus gerochii Kaminski \& Gradstein and ?Eggerelloides aff. E. propinqus (Brady). These taxa appear in the lower Eocene in the Carpathian flysch (e.g. Jurkiewicz, 1967; Morgiel \& Szymakowska, 1978; Geroch \& Koszarski, 1988; Bubik, 1995a, 2006; Kaminski \& Gradstein, 2005) and occur only in the Eocene. Caudammina ovula (Grzybowski), Glomospira diffundens Cushman \& Renz, Caudammina excelsa (Dylążanka) and Hormosina velascoensis (Cushman) occur irregularly as accompanying single taxa. These taxa are common in the uppermost Cretaceous-Paleocene and range to the lower Eocene (Jurkiewicz, 1967; Bąk, 2004; Kaminski \& Gradstein, 2005; Waśkowska, 2011a,b).

The presence of ?Saccamminoides carpathicus Geroch in only one sample in the Krzesławice section is a weak biostratigraphical marker and to confirm the biostratigraphical result adjacent levels were sampled. Mudstones lying below the Hieroglyphic beds contain agglutinated foraminifera assemblages of Paleocene age, with numerous Caudammina, Hormosina and Rzehakina, among which Rzehakina fissistomata (Grzybowski) is present (Fig. 4). This species is known in the Carpathians exclusively from the Paleocene (Morgiel \& Olszewska, 1981; Geroch \& Nowak, 1984; Geroch \& Koszarski, 1988; Olszewska, 1997; Bubik et al., 1999; Waśkowska-Oliwa, 2008; and papers cited therein), while deposits about $150 \mathrm{~m}$ above contain relatively numerous Reticulophragmium amplectens (Grzybowski), indicating a middle Eocene (Lutetian) age. Analysed assemblages with increased numbers of Trochammina in the Krzesławice section thus represent the lower Eocene (Ypresian). The biostratigraphical data thus indicate superposition in the studied deposits.

In the Carpathians two lower Eocene foraminiferal biozones are distinguished. The older one - Glomospira diverse species (div. sp., with an acme of the genus Glomospira) - is characteristic for the lower Ypresian and, following it, the index species

Explanation of Plate 1. figs 1-2. General views of foraminiferal assemblages: 1, Janoska 132/10/07; 2, Krzesławice 95/65/09. figs 3-6. Trochammina sp.: a, dorsal side; b, ventral side; c, transparent (3 - sample Krzesławice 93/63/09 specimen no. t13; 4 - Krzesławice 95/65/09 specimen no. t17; 5 - Janoska 135/13/07 specimen no. t140; 6 - Janoska 135/13/07 specimen no. t135). fig. 7. Bathysiphon sp. with numerous muscovite clasts in the test (Janoska 135/13/07 specimen no. b123). 


\section{KRZESŁAWICE SECTION}

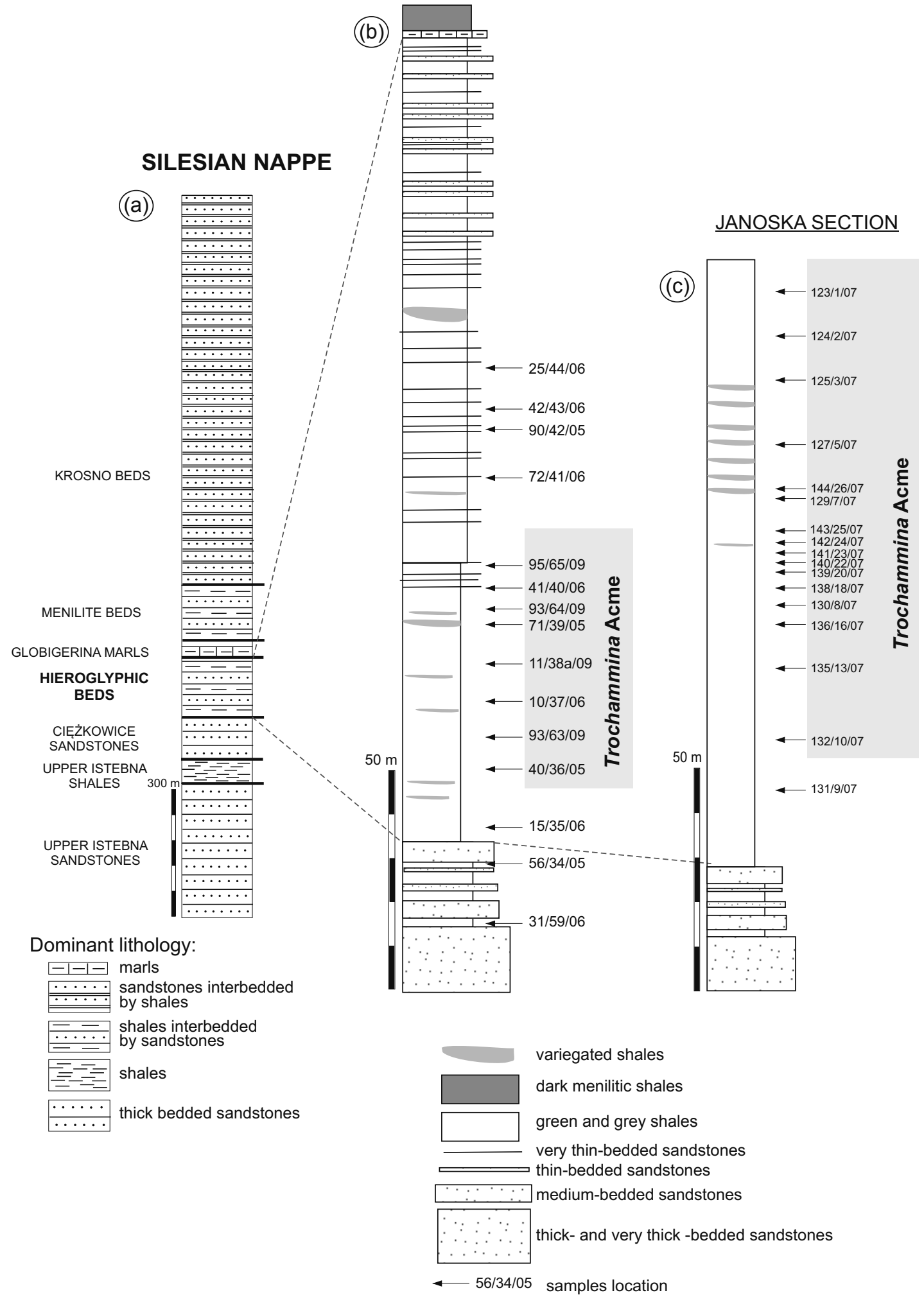

Fig. 3. Lithological logs of analysed profiles of Hieroglyphic beds $(\mathbf{b}, \mathbf{c})$ with sample points and their position in general log of Paleogene deposits of Silesian Nappe (a). 

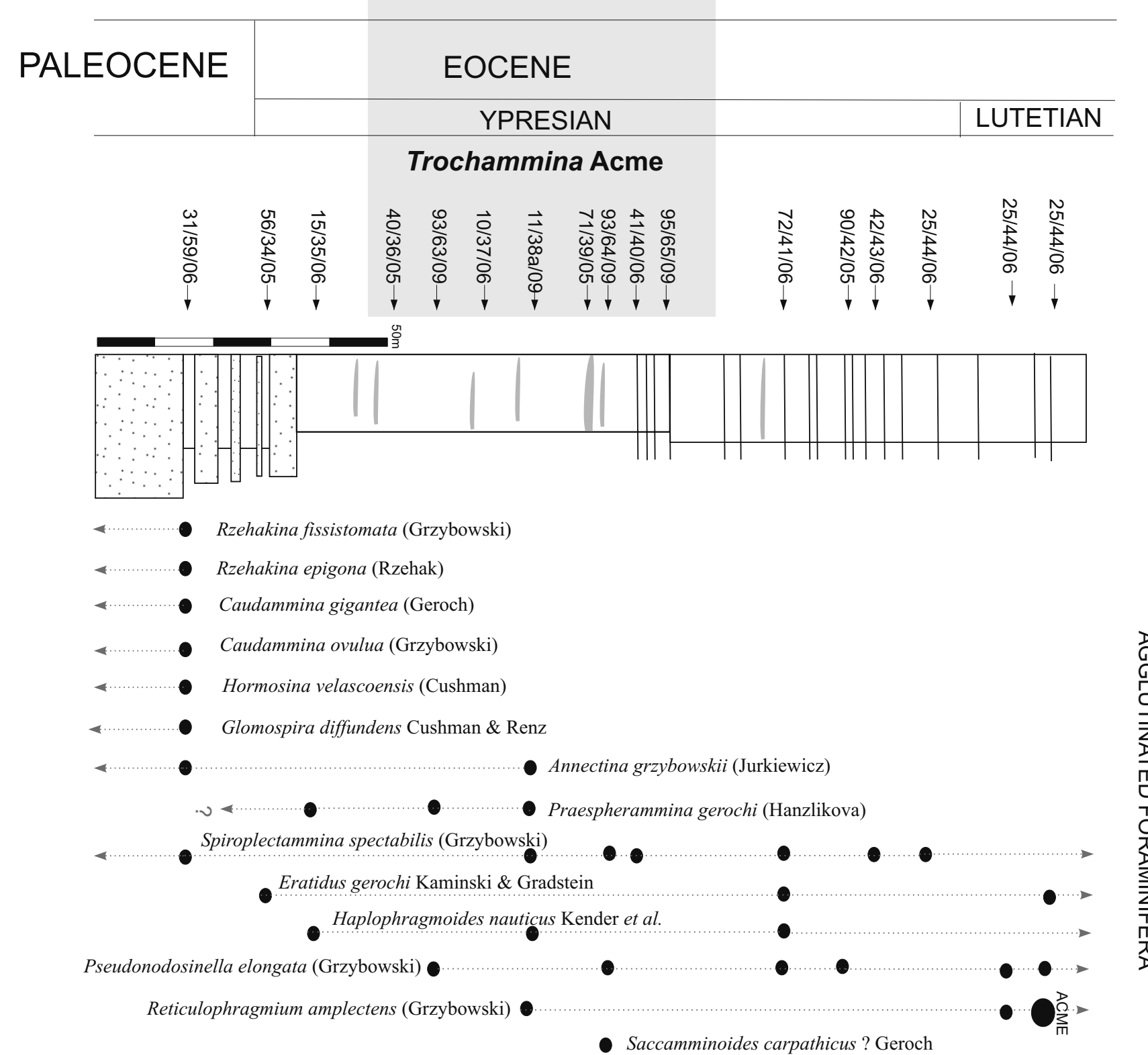

- Subbotina hornibrooki (Bronniman)

Fig. 4. Distribution of biostratigraphically important taxa against lithological log of lower Hieroglyphic beds in Krzesławice area. Arrows indicate the continuation of species ranges in the lower or higher part of the lithostratigraphic log. 
MORPHOGROUPS

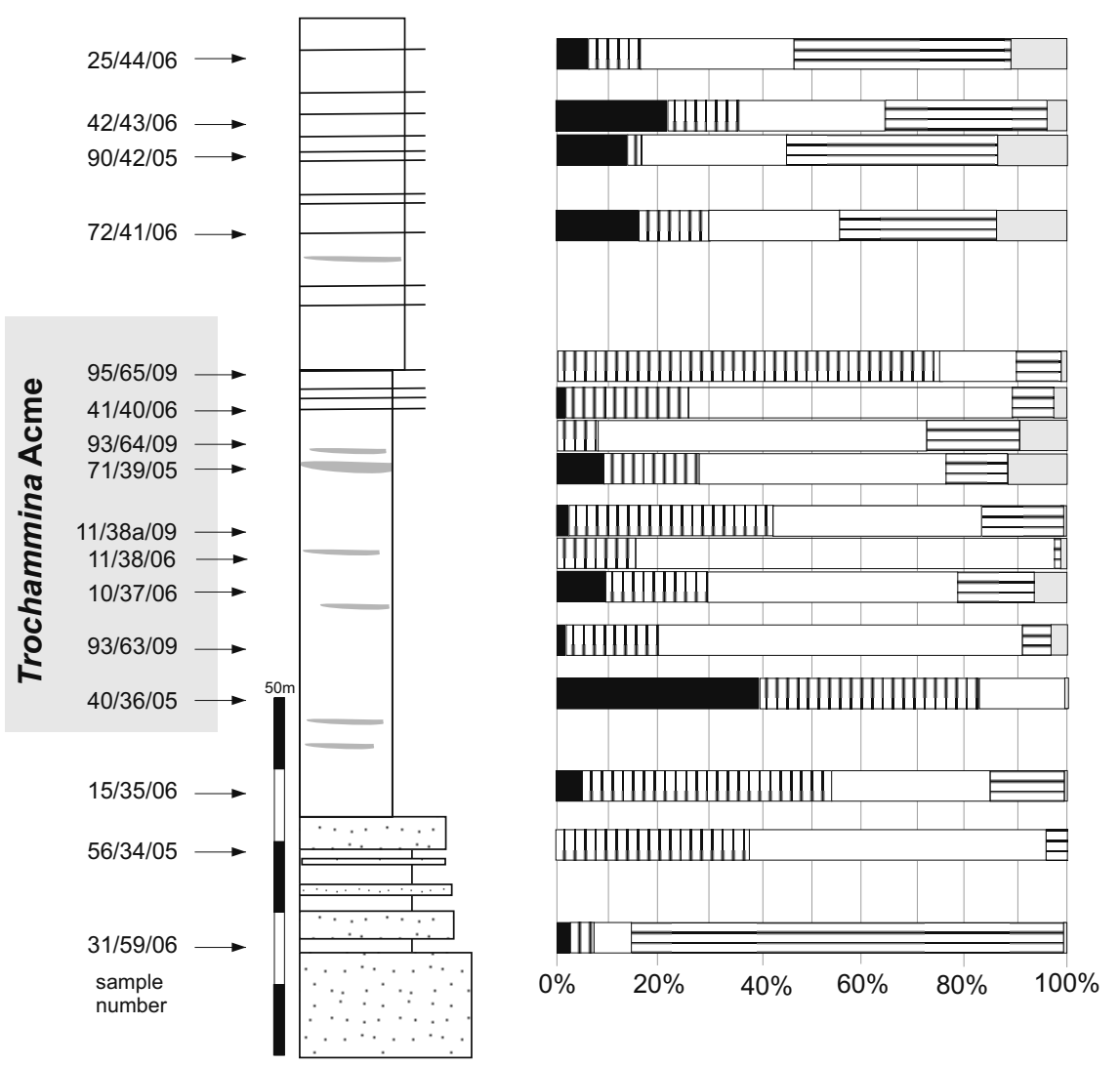

\% Trochammina

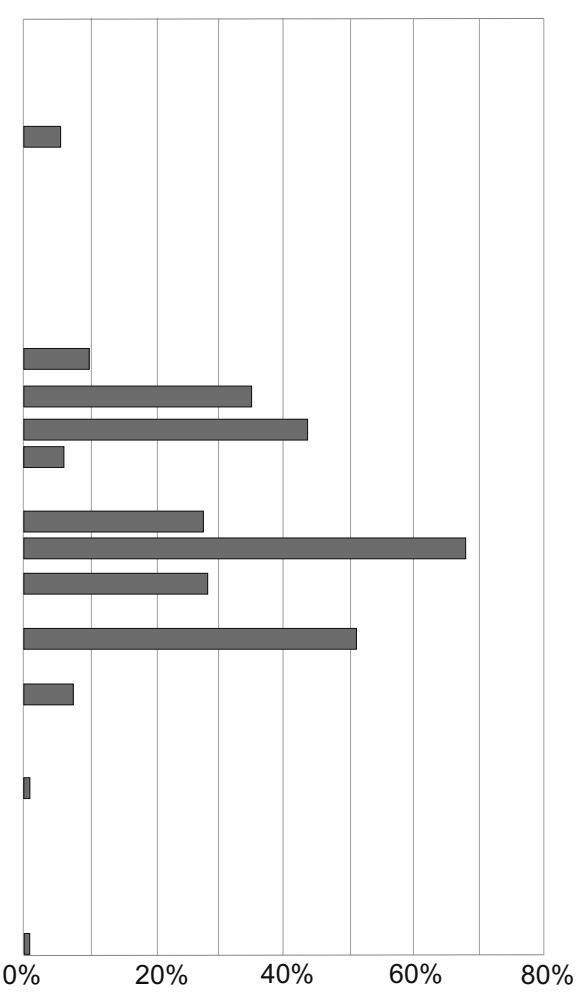

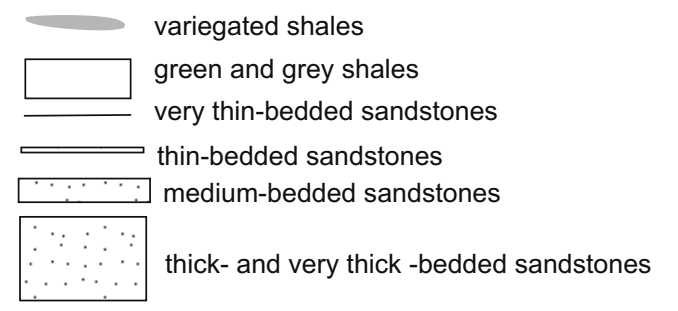

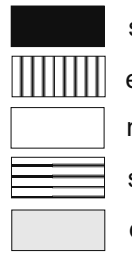

sessile erect epifauna (tubular forms)

epifauna - shallow infauna (tubular forms e.g. Bathysiphon)

mobile epifauna - others

shallow and deep infauna (high trochospiral and streptospiral coil)

deep infauna (elongated and tapered forms)

Fig. 5. Distribution of basic morphogroups and Trochammina in lower Hieroglyphic beds at Krzesławice section.

Saccamminoides carpathicus Geroch defines the upper Ypresian (sensu Morgiel \& Olszewska, 1981; Olszewska, 1997). In the analysed sections the Glomospira div. sp. biozone is not present. In the depositional environment of the Heiroglyphic beds the assemblages characteristic for the Glomospira div. sp. biozone were replaced by the small-sized Trochammina assemblages (Plate 2).

In some Krzesławice samples, planktonic foraminifera have been identified as poorly preserved accessory forms (often as internal moulds), i.e. Subbotina linaperta Finlay, Subbotina hagni? (Gohrbandt), Subbotina yeguaensis (Weinzierl \& Applin), Subbotina corpulenta (Subbotina) and Catapsydrax unicavus Bolli (Fig. 4), cosmopolitan taxa known from the Eocene of the Carpathians. They appear in the Ypresian, in the younger part of this interval and survived until the late Eocene (Pearson et al., 2006). In sample 93/64/09 (lower part of deposits with small-sized Trochammina assemblages), Subbotina hornibrooki (Brönnimann) is present, typi- cal for the early Ypresian. Slightly higher in the profile Subbotina linaperta Finlay and Subbotina yeguaensis (Weinzierl \& Applin) are present in one sample with the agglutinated species Reticulophragmium amplectens (Grzybowski), Haplophragmoides nauticus Kender et al. and Annectina grzybowskii (Jurkiewicz) (Fig. 4). These foraminifera co-occur only in the Ypresian. The stratigraphic range for Annectina grzybowskii (Jurkiewicz) is upper Cenomanian to Paleocene (Olszewska et al., 1996; Kaminski \& Gradstein, 2005), but this form is identified also in the Eocene in the Carpathians (Hanzlikova \& Pesl, 1964; Waśkowska-Oliwa, 2005; Cieszkowski et al. 2006; Waśkowska, 2011b). All of the aforementioned planktonic species are present below the acme of Reticulophragmium amplectens (Grzybowski). Taking into account the taxonomical composition of agglutinated and planktonic foraminifera and their biostratigraphical ranges, the assemblages with numerous small-sized Trochammina occurred in the Ypresian. 

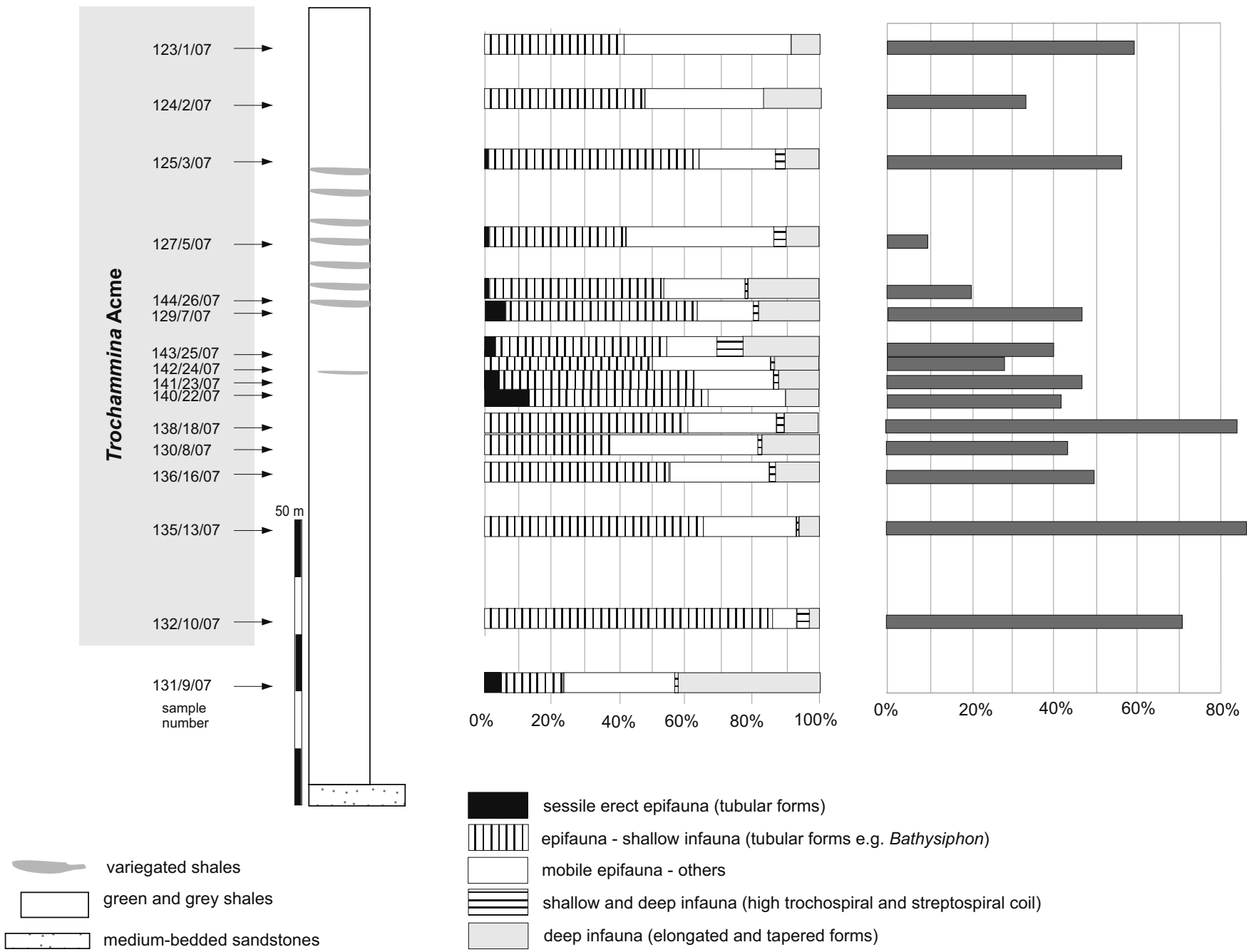

sessile erect epifauna (tubular forms)

epifauna - shallow infauna (tubular forms e.g. Bathysiphon)

mobile epifauna - others

shallow and deep infauna (high trochospiral and streptospiral coil)

deep infauna (elongated and tapered forms)

Fig. 6. Distribution of basic morphogroups and Trochammina in lower Hieroglyphic beds at Janoska.

THE SMALL-SIZED TROCHAMMINA ASSEMBLAGE Assemblage composition, taxonomic diversity

Agglutinated taxa are dominant in the analysed assemblages and calcareous forms are uncommon. Fish teeth are an associated component and are especially prevalent in the Krzesławice section. Agglutinated forms are in a good state of preservation; most of them have diagnostic characteristics, allowing taxonomic determination at the specific or generic level. A typical feature of the assemblages is the presence of coarse- and medium-grained forms (e.g. Bathysiphon, Trochammina, Reophax, Karrerulina). Specimens of Trochammina accounted for an average of $42 \%$ of the assemblages in Krzesławice and $47 \%$ of the assemblages in Janoska (Figs 5 and 6). These values should be regarded as minimum values. The real percentage of Trochammina could be higher, because taxa such as the tubular foraminifera (numerous in the analysed material) and uniserial multichambered forms occur as fragments and each was counted as an individual specimen, so their actual abundance is certainly overstated. Trochammina in the Krzesławice section reach almost $70 \%$ and at Janoska more than
$80 \%$ (Figs 5 and 6), and such assemblages can be called monotaxa associations. Another important large group of microfossils are the tubular forms belonging to the genus Bathysiphon (Figs 5 and 6). These are cosmopolitan foraminifera in the Carpathian flysch, and are usually represented by test fragments. Another important group of foraminifera, with proportions of a few to several percent are the genera Paratrochamminoides and Trochamminoides, Recurvoides and Thalmannammina; a small percentage of the assemblage is comprised of Ammodiscus and Glomospira. Other cosmopolitan foraminifera are poorly represented, for example Placentammina, Arthrodendron, Haplophragmoides, Karrerulina and Pseudonodosinella (Plates 3 and 4).

Scarce calcareous foraminifera were occasionally found in individual samples from the Krzesławice section (nos 93/63/09, $11 / 38 \mathrm{a} / 09,93 / 64 / 09,41 / 40 / 09)$. They consist of single or a few specimens. The state of preservation was poor, most often the shell surface was dissolved, partially or completely, resulting in internal moulds. Planktonic foraminifera are represented primarily by the so-called large Subbotina (e.g. S. yeguaensis (Weinzel \& 


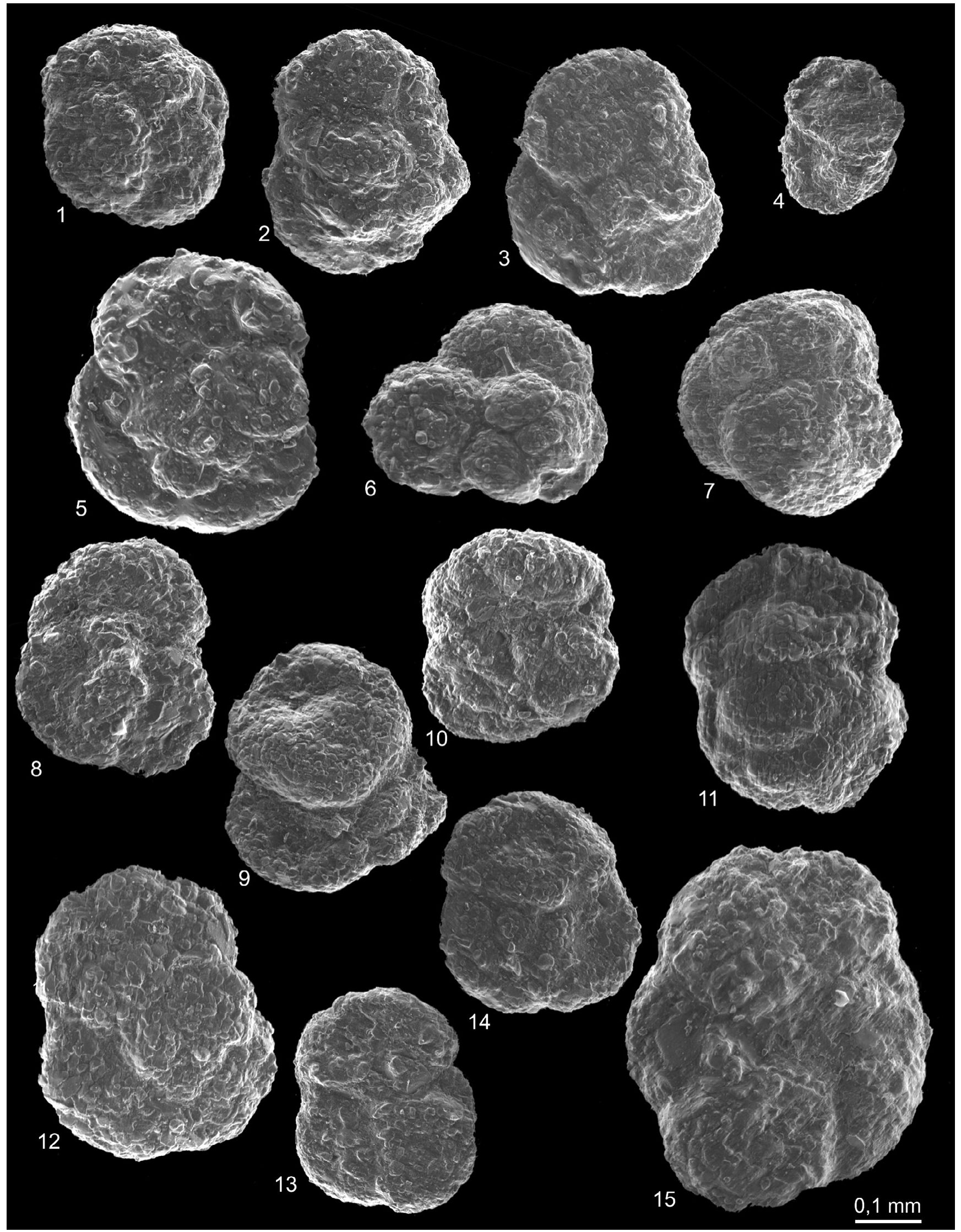


Applin), S. corpulenta (Subbotina), S. hagni? (Gohrbandt) and $S$. linaperta (Finlay)) (Plate 4). Calcareous forms include Nuttallides truempyi (Nuttall) and Oridorsalis umbonatus (Reuss). In assemblages with numerous Trochammina the average overall generic diversity is 15 . Excluding Trochammina, the average number of species is 23. In the underlying Paleocene deposits 45 species belonging to 24 genera were found, while in overlying deposits 36 species belonging to 21 genera were recorded. Small-sized Trochammina assemblages show a decreasing trend in diversity in comparison with assemblages from surrounding deposits.

\section{Size of foraminiferal tests}

Another trend observed in assemblages with numerous Trochammina is a decrease in the size of all foraminiferal tests. Assemblages are represented mainly by specimens that measure $0.2-0.4 \mathrm{~mm}$ length (or diameter); larger forms are significantly more numerous in deposits underlying and overlying the Trochammina assemblages.

Size differences are clearly visible on the tests of specimens of one taxonomic group. The genus Trochammina was chosen for measurement in samples from the Krzesławice section.

Dimensions of Trochammina specimens within the size range $0.20-0.35 \mathrm{~mm}$ are dominant and represent $80-95 \%$ of Trochammina. Larger forms, with diameter (length) above $0.45 \mathrm{~mm}$ are rare or absent; specimens smaller than $0.2 \mathrm{~mm}$ are more common. In assemblages from the under- and overlying deposits the forms smaller than $0.35 \mathrm{~mm}$ make up to $40 \%$ of Trochammina, and the most common forms occur in the size range $0.31-0.45 \mathrm{~mm}$, with some specimens exceeding a diameter of $0.5 \mathrm{~mm}$.

\section{Morphogroup distribution}

Benthic foraminifera live at the surface of the sea floor and within the upper few centimetres of the sediment. One of the easily identifiable effects of environmental adaptation is test morphology. It is possible to estimate palaeoecological parameters of the assemblage, indicating its depositional environment on the basis of the test shape, as has been previously shown by Jones \& Charnock (1985) with later modifications (see Murray et al., 2011 and papers cited therein). This has been successfully used for palaeontological analysis of Mesozoic and Cenozoic palaeoenvironments (Coccioni \& Galeotti, 1994; Nagy et al., 1995; Bąk et al., 1997; Peryt et al., 1997; Mancin, 2001; Waśkowska-Oliwa \& Leśniak, 2003; Bąk, 2004; Kender et al., 2008; Setoyama et al., 2011).

In the analysed material, an overwhelming dominance of forms connected with the sediment surface (epifauna and Bathysiphon) is clear, which can range from $70-98 \%$ in assemblages from both profiles (Figs 5 and 6). The largest group consists of mobile foraminifera (predominantly Trochammina), colonizing the surface of the sediment, the tests of which are typically flattened, low trochospiral, planoconvex and concavoconvex. Apart from Trochammina they are represented by various species of Ammodiscus, Glomospira, Trochamminoides and Paratrochamminoides. The increase of epifauna is associated with monogeneric Trochammina dominance, and with a decrease in the abundance of deep migrating infauna.

The infaunal group that is significantly reduced is the shallowdeep infauna, represented by high-trochospiral and trochospiral forms such as Recurvoides and Thalmannammina.

An important component of the analysed assemblages is Bathysiphon, belonging to the tubular forms, often incorporated into the group of erect epifauna. Research on modern assemblages indicates that Bathysiphon can function as an infaunal-epifaunal form, choosing a horizontal or nearly horizontal position in the sediment (Gooday et al., 2002). This form builds very long tubular chambers, attaining a length of a few centimetres, with irregular thickness and constrictions in many places (Małecki, 1973). This type of test morphology is not conducive to continued functioning as erect epifauna. Bathysiphon most often inhabits the subsurface parts of the bottom sediment, intensely penetrating them, being able to move quite fast within the sediment (e.g. Gooday et al., 1992; Geslin et al., 2004). It is included here in the deposit feeders (Gooday et al., 2002).

\section{THE ASSEMBLAGE IN VARIEGATED SHALE INTERCALATIONS}

Both analysed profiles contain intercalations of variegated shales with a thickness from a few to tens of centimetres. In comparison with the typical grey mudstones with numerous Trochammina, the variegated shales are finer-grained, with increased amounts of clay minerals and lesser amounts of muscovite and rare pyrite. In the variegated deposits, the TOC values increase rapidly to $0.03-$ $0.38 \%$, with a concomitant slight increase in the amount of carbonate reaching $6 \mathrm{~g} \mathrm{~kg}^{-1}$. Foraminiferal assemblages in the variegated shales are represented by sample 71/39/09 of the Krzesławice section, and sample 127/5/07 from Janoska. Samples Janoska 130/8/07 and Janoska 144/26/07 were collected from mixed variegated shale and typical Hieroglyphic beds. The taxonomic composition of assemblages from the variegated shales differs significantly from those characteristic for the small-sized Trochammina assemblages from surrounding deposits. The main feature is the small amount of Trochammina, which is estimated here as $6.5 \%$ in the Krzesławice section, giving a value 8 times lower than average, and $9 \%$ in the Janoska section which is 5 times lower than average (Figs 5 and 6). The decrease in Trochammina does not affect the solid trend in the distribution of morphogroups and the proportion of the mobile epifauna, which is preserved in the surrounding deposits, because it is compensated by an increase in the number of other foraminifera incorporated into this group, especially with species of Ammodiscus, Glomospira, Paratrochamminoides and Trochamminoides. The group of deep migrating infauna is here much more numerous and taxonomically diversified.

Explanation of Plate 2. Trochammina, SEM images. fig. 1. sample Janoska135/13/07, specimen no. t7. fig. 2. sample Janoska 135/13/07, specimen no. t11. fig. 13. sample Janoska 135/13/07, specimen no. t32. fig. 14. sample Janoska 135/13/07, specimen no. t35. fig. 3. Janoska 123/10/07, specimen no. t16. fig. 4. sample Janoska 123/10/07, specimen no. t20. fig. 6. Janoska 123/10/07, specimen no. t24. fig. 12. sample Janoska 123/10/07, specimen no. t33. fig. 5. sample Krzesławice 40/36/07, specimen no. t7. fig. 7. sample Krzesławice 40/36/07, specimen no. t9. fig. 8. sample Krzesławice 40/36/07, specimen no. t14. fig. 9. sample Krzesławice 40/36/07, specimen no. t19. fig. 10. sample Krzesławice 40/36/07, specimen no. t45. fig. 11. sample Krzesławice 40/36/07, specimen no. t 56. fig. 15. sample Krzesławice 40/36/07, specimen no. t78. 


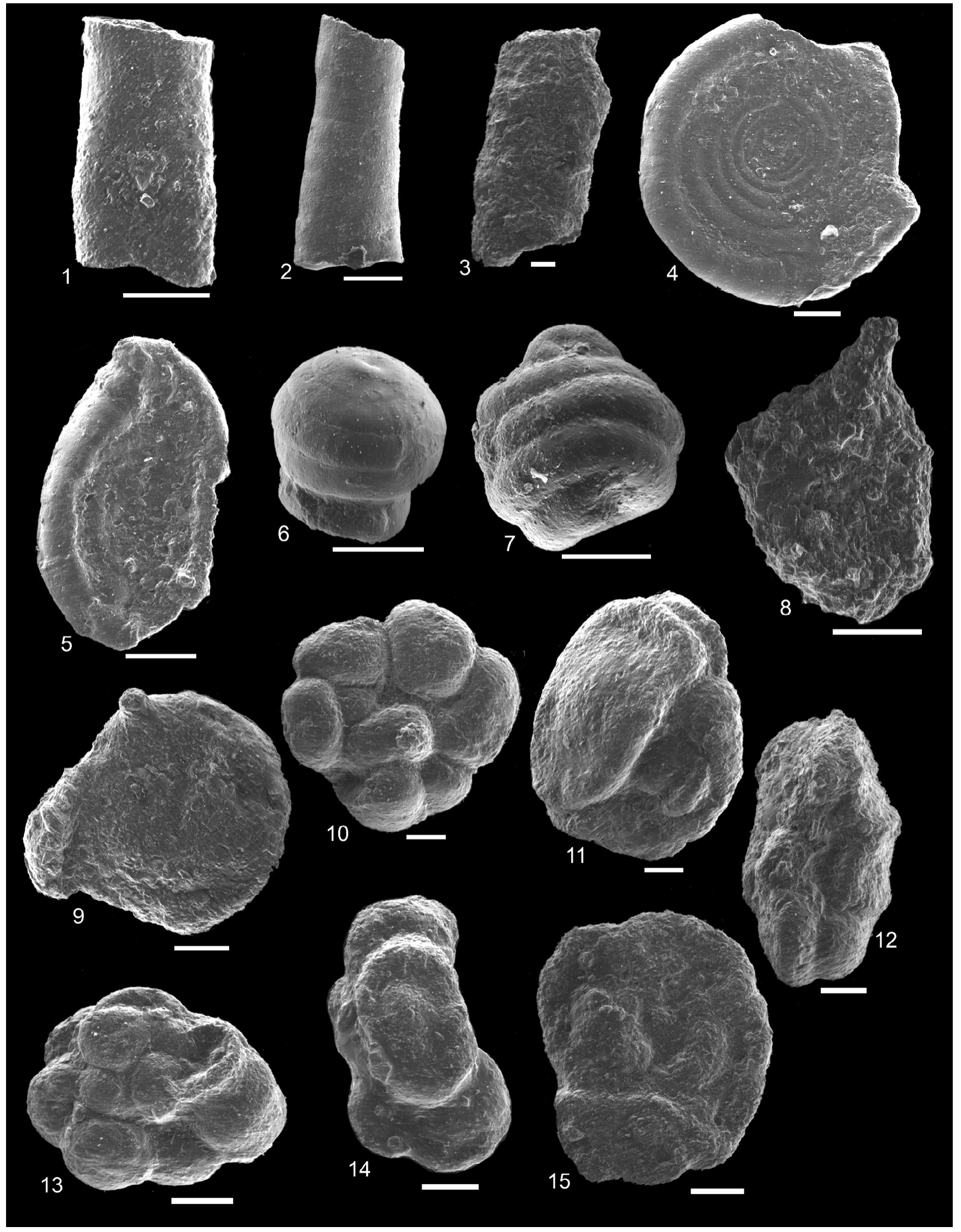


It should also be noted that the variegated shales assemblage is abundant in the Krzesławice section, where the number of specimens in a single sample exceeds 3100, and in the Janoska profile where it exceeds 10000 foraminifera. These high faunal abundances may be the result of sedimentary condensation, indicating a decrease in the supply of terrigenous material.

In the variegated shales the biodiversity increases. Although, the number of genera is similar, as in the small-sized Trochammina assemblages, the number of species is higher and increases to 35 species.

\section{DISCUSSION \\ Distribution of lower Paleogene Trochammina in the Carpathians}

In the deep-water setting of the Outer Carpathians, Trochammina is frequent in all Paleogene facies, with the following taxa: Trochammina globigeriniformis (Parker \& Jones), Trochammina quadriloba Geroch (Ammogloborotalia quadriloba, as re-assigned by Kaminski et al., 2007), Trochammina altiformis Cushman \& Renz (Trochamminopsis altiformis as re-assigned by Kaminski \& Gradstein, 2005) and Trochammina bulloidiformis (Grzybowski) (Geroch, 1959, 1960; Geroch et al. 1967; Jurkiewicz, 1967; Morgiel \& Szymakowska, 1978; Malinowska, 1984; WaśkowskaOliwa, 2005). They are known not only from individual Carpathian basins, but also reported from other regions of Tethys (Kuhnt \& Kaminski, 1990; Kuhnt \& Collins, 1996; Kaminski \& Gradstein, 2005). They are usually recorded in the Carpathian literature as an accessory component of diverse multispecies assemblages. It is also possible that additional undescribed trochamminid species are present in the assemblage, since the taxonomy of this group is still unclear. None of the Trochammina species is similar to taxa from modern salt marshes described by Scott \& Medioli (1980). The trochamminids are usually present in assemblages from Outer Carpathian deposits, but they occur as single specimens. Large numbers of Trochammina species are found in the lower Paleogene deposits of the Eastern Outer Carpathians that are included into the Dukla Nappe. The occurrence of Trochammina there is characteristic for late Paleocene and early Eocene age assemblages. A Recurvoides-TrochamminaTrochamminoides and Paratrochamminoides biofacies has been distinguished in the Paleocene assemblages (Bak, 2004). However, in the Hieroglyphic beds of the Silesian Nappe, assemblages with numerous Trochammina have been indentified (Waśkowska, 2012). This group is dominated by foraminifera with a free test, low trochospiral coiling, evolute, dorsal side flattened and ventral side convex; their chambers increase rapidly in size, with the last whorl containing 4-3.5 chambers, and they have a coarsely agglutinated wall (Plates 1 and 2). Their size is highly variable, from $0.17-0.62 \mathrm{~mm}$. The largest forms are morphologically referred to
Trochammina umiatensis Tappan, whereas the distinguishing features of the small forms are somewhat obscured by the coarsely agglutinated wall. The Trochammina specimens illustrated by Bubik (1995b) and Bąk (2004) from deep-water Paleogene deposits of the Carpathians show some resemblance to the fine specimens in the material analysed in this study. Determination of the species-level taxonomy will require further investigation.

\section{Trochammina assemblages and global climatic change}

The early Eocene was a time interval associated with the reconstruction of benthic fauna in deep-water basins, especially marked in the Outer Carpathians basins (Bubik, 1995a; Bak, 2004; Waśkowska-Oliwa, 2005). This trend is global in extent and is associated with changes in palaeoclimate in the late Paleocene, especially connected to the Paleocene-Eocene Thermal Maximum (PETM; Tjalsma \& Lohman, 1983; Miller et al., 1987; Kennett \& Stott, 1991; Pak \& Miller, 1992; Kaiho et al., 1993, 1996; Thomas \& Shackleton, 1996; Thomas, 1998; Pardo et al., 1999; Galeotti et al., 2004; Bąk \& Barwicz-Piskorz, 2005), which is associated with changes in the carbon cycle (Boersma et al., 1987). As a result, a mass extinction of many species of benthic foraminifera is observed in the deep-sea environment, and the event is identified as the largest global extinction of calcareous benthonic foraminifera (Thomas, 1998; Alegret et al., 2010).

The early Eocene assemblages are known as a new post-crisis fauna; among them there are many opportunistic long-living forms that persisted from the Cretaceous and which managed to survive the late Paleocene crisis (Kaminski et al., 1996). In the Carpathian basins post-crisis assemblages are characteristic because they have low taxonomic diversity with numerous small forms of Glomospira, with two species dominating (Jurkiewicz, 1967; Bubik, 1994, 1995b; Bąk et al., 1997; Waśkowska-Oliwa, 2000; Bąk, 2004; Oszczypko et al., 2005; Cieszkowski et al., 2011; Waśkowska, 2011a; Arreguin-Rodriguez et al., 2013). Glomospira assemblages are usually found in hemipelagic variegated deep-sea deposits (Morgiel \& Olszewska, 1981, 1982; Waśkowska-Oliwa, 2000; Bąk, 2004; Cieszkowski et al., 2004; Bąk \& BarwiczPiskorz, 2005) representing areas of low sedimentation rate (Kaminski et al., 1989). The successive rebuilding of the structure of the benthic foraminiferal assemblage was a gradual and longterm process that lasted until the middle Eocene, when conditions once again became favourable for the development of benthos in low-energy conditions. At this time benthic foraminiferal assemblages reached their maximum diversity, and at the same time the epi- and infaunal niches were evenly inhabited (Kaminski et al., 1999). An interval of restructuring of the benthic assemblage is associated with the later phase of the early Eocene, which is characterized by the presence of Saccamminoides carpathicus (Geroch). The reconstruction was not uniform, took place at different rates

Explanation of Plate. 3. Agglutinated foraminifera from Trochammina assemblages, SEM images. fig. 1. Bathysiphon sp. (sample Janoska 132/10/07, specimen no. 23). fig. 2. Bathysiphon sp. (sample Janoska 132/10/07, specimen no. 34). fig. 3. Bathysiphon sp. (Krzesławice 40/36/05, specimen no. b14). fig. 4. Ammodiscus incertus (d'Orbigny) (Janoska 132/10/07, specimen no. a3). fig. 5. Ammodiscus peruvianus Berry (Janoska 123/1/07, specimen no. a4). fig. 6. Glomospira charoides (Jones \& Parker) (Janoska 123/1/07, specimen no. g7). fig. 7. Glomospira charoides (Jones \& Parker) (Janoska 123/1/07, specimen no. g15). fig. 8. Saccammina grzybowskii (Schubert) (Janoska 123/1/07, specimen no. s2). fig. 9. Placentammina placenta (Grzybowski) (Krzesławice 40/36/05, specimen no. pl2). fig. 10. Paratrochamminoides deflexiformis (Noth) (Krzesławice 40/36/05, specimen no. pr34). fig. 13. Paratrochamminoides deflexiformis (Noth) (Krzesławice 40/36/05, specimen no. pr14). fig. 11. Paratrochamminoides sp. (Krzesławice 40/36/05, specimen no. pr15). fig. 12. Trochamminoides subcoronatus (Grzybowski) (Janoska 123/1/09, specimen no. tr10). fig. 14. Trochamminoides subcoronatus (Grzybowski) (Janoska 123/1/09, specimen no. tr17). fig. 15. Trochamminoides dubius (Grzybowski) (Janoska 123/1/07, specimen no. tr19). Scale bars 100 $\mu$ m. 


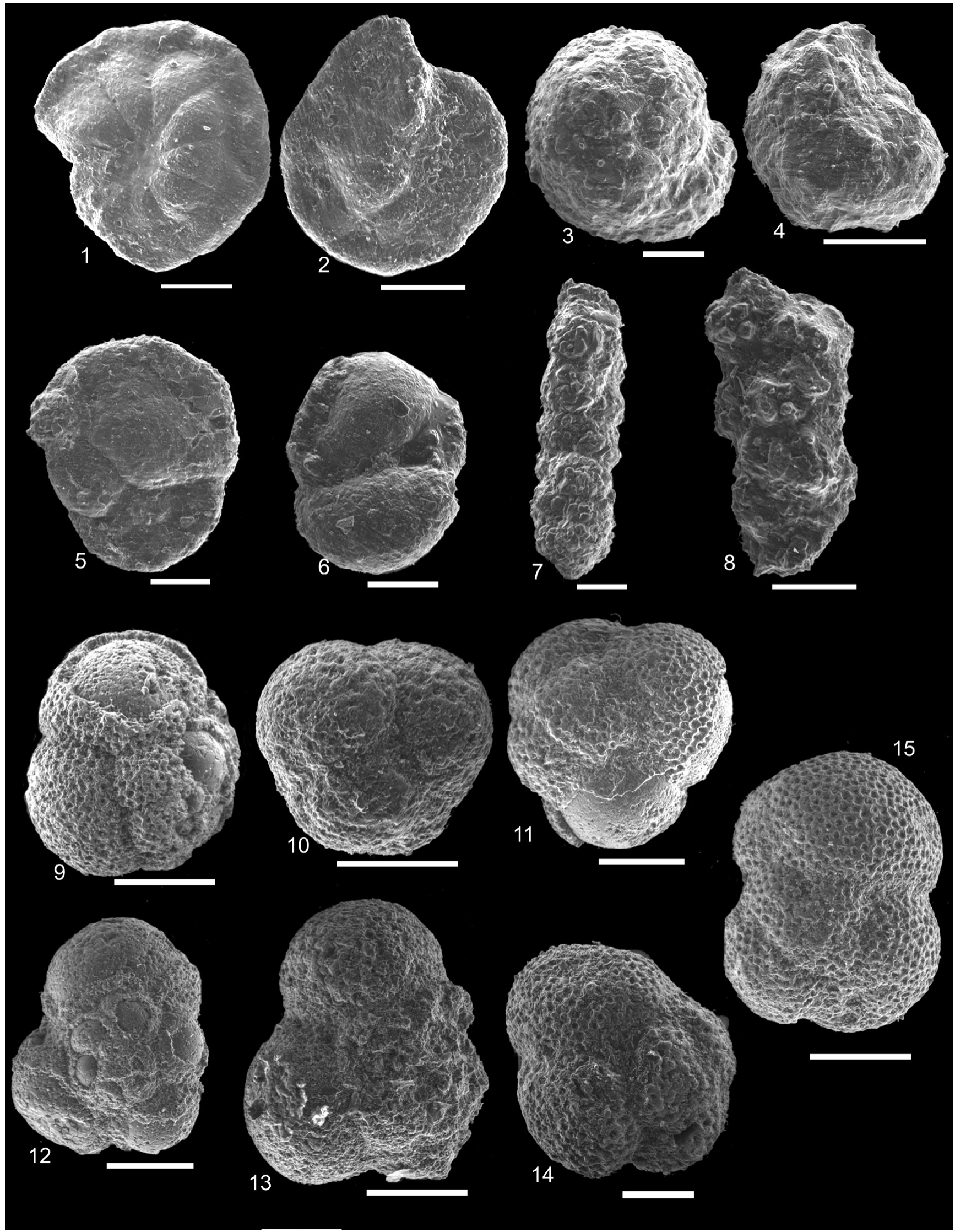


and was dependent on many factors, most of all on the environmental conditions.

In the Silesian Basin, the fauna became differentiated very slowly during the early Eocene. The structure of the Trochammina assemblage is very similar to the slightly younger assemblages of the Glomospira biofacies, but they differ in the composition of the dominant forms. In the studied material, assemblages characteristic for the Glomospira biofacies were not found. Directly above the typical Paleocene assemblages, ones with little distinctive fauna are present, followed by assemblages of the Trochammina biofacies. Such a record relates to the grey mudstone deposits. However, within the profile in which the Trochammina biofacies is the typical association, intercalations of variegated mudstone appear, in which a sharp increase in Glomospira is present and taxonomic diversity is higher. The lack of Glomospira biofacies could be an effect of local replacement by the more environmentally tolerant Trochammina biofacies in the Silesian Basin.

\section{Opportunistic Trochammina assemblages}

Trochammina is recorded in the Carpathian basins from the Cretaceous to Oligocene, but it appears rather as an accessory taxon, rarely represented by large numbers of specimens. Increased numbers have been recorded in lower Paleogene from Skole and Dukla basins (Bąk et al., 1997; Bąk, 2004). Numerous reports in the literature refer to the mass appearances of smallsized Trochammina in shallow-water environments, where the dominance of this taxon is associated with stressful environmental conditions, such as reduced salinity, oxygen hypoxia, stormy environments, after earthquakes, low or high TOC values (Nagy et al., 1988, 2010; Hollis et al., 1995; Rasmussen et al., 2003; Barbosa et al., 2005; Hawkes et al., 2010; Hromic et al., 2012). It is also common in brackish environments (Jones, 1988; Nagy et al., 1995). Trochammina is considered to be an opportunistic form (Scott et al., 1983; Murray, 1991; Nagy et al., 1995), which can create well-functioning associations in marsh environments that are unfavourable for other foraminifera. It is also referred to as an invasive form (McGann et al. 2012), rapidly colonizing new environments, adaptable for settling new areas (Alve, 1999). Thus, its mass appearance in deep-sea environments could have been the result of adverse benthic conditions during the Eocene.

Well-developed Trochammina-dominated assemblages in the lower Eocene of the Silesian Basin may have filled ecological niches that had been opened up after the Paleocene-Eocene benthic foraminiferal extinction event. Trochammina is an epifaunal taxon, functioning on the surface of the sediment, known as an active or passive herbivore. It is common in high-energy environments (Nagy et al., 1995) and includes forms with high ecological tolerance (Nagy et al., 1988).
A significant, stable and relatively numerous component of assemblages with small-sized Trochammina is Bathysiphon. Bathysiphon, next to Arthrodendron, belongs to the foraminifera with largest overall dimensions found in the analysed material. Bathysiphon builds tubular tests, which are found as fragments in the analysed material. The length of the tests differs - some modern species of Bathysiphon are classified as macrofauna, reaching a length of over $10 \mathrm{~cm}$ (Gooday et al., 2002). It is difficult to estimate the original amount of Bathysiphon, because of the differing shell parameters which can make up these forms. One of the best preserved and more or less complete examples of Bathysiphon in the deep-sea Carpathian deposits (locality shore of Rożnowskie Lake - Silesian Nappe, Hieroglyphic beds) reaches a length of about $3 \mathrm{~cm}$ (Małecki, 1973). Taking into account the size of the Bathysiphon fragments, their number should be much lower. Bathysiphon, belonging to simple foraminifera, represents epifauna and shallow infauna. It lives on the surface of the sediment or in the bottom sediment, in an almost horizontal position, frequently moving. This form is a deposit-feeder (Gooday et al., 1992) and it is considered to be the main bioturbating organism in the bottom sediment (Geslin et al., 2004). Bathysiphon is cosmopolitan (Kaminski \& Gradstein, 2005), is characteristic of deepwater assemblages and is abundantly represented in the Carpathian basins. It has a high ecological tolerance - the highest known among flysch-type foraminifera. Evidence of this is the presence of Bathysiphon as the only foraminifera in deposits indicating high energy or dysoxic environments (Ortiz et al., 2011). This type of monotaxa assemblage is very common in the Carpathian flysch. Laboratory tests confirm that Bathysiphon is tolerant of low oxygen conditions (Geslin et al., 2004). Taking into account the distribution of morphogroups, assemblages with numerous Trochammina are dominated by forms living on the surface of the sediment and its uppermost layer. These forms represent a group of actively moving foraminifera, obtaining their food from the sediment (Jones \& Charnock, 1985; Kuhnt et al., 1996).

A special feature of the Trochammina biofacies is the dwarfing of the assemblage. It concerns not only Trochammina, but also occurs in other forms, i.e. Ammodiscus, Glomospira, Karrerulina, Trochamminoides, Paratrochamminoides, Recurvoides, etc.. This trend is observed in assemblages that inhabit environments with rapidly changing environmental parameters (Nagy et al., 2010). The small size is a strategy known also among other primitive organisms when under specific conditions the reproduction rate increases while dimensions decease (Harries et al., 1996; Thomas, 1988; Alegret et al., 2010). The result is a relatively rapid increase in the number of dwarfed forms of the species (Benhard, 1986; Kaiho, 1999) and functioning monotaxa assemblages or assemblages with one species dominant. Such a strategy is used by

Explanation of Plate. 4. Benthic and planktonic foraminifera from Trochammina assemblages, SEM images. fig. 1. Haplophragmoides walteri (Grzybowski) (sample Krzesławice 11/38a/09, specimen no. h3). fig. 2. Haplophragmoides walteri (Grzybowski) (Janoska 132/10/07, specimen no. h6). fig. 3. Recurvoides walteri (Grzybowski) (Janoska 132/1/09, specimen no. r45). fig. 4. Recurvoides walteri (Grzybowski) (Janoska 132/10/09, specimen no. r23). fig. 5. Cystammina sp. (Krzesławice 11/38a/09, specimen no. c2). fig. 6. Cystammina sp. (Krzesławice 11/38a/09, specimen no. c6). fig. 7. Karrerulina conversa (Grzybowski) (Krzesławice 11/38a/09, specimen no. k2). fig. 8. Karrerulina horrida (Mjatliuk) (Janoska 123/1/09, specimen no. 13). fig. 9. Subbotina hornibrooki (Brönniman) (Krzesławice 93/63/09, specimen no. p1). fig. 10. Subbotina hornibrooki (Brönniman) (Krzesławice 93/63/09, specimen no. p2). fig. 11. Subbotina hornibrooki (Brönniman) (Krzesławice 93/63/09, specimen no. p3). fig. 12. Subbotina yeguaensis (Weinzierl \& Applin) (Krzesławice 41/40/06, specimen no. p8). fig. 13. Subbotina yeguaensis (Weinzierl \& Applin) (Krzesławice 93/64/09, specimen no. p16). fig. 14. Subbotina corpulenta (Subbotina) (Krzesłwice 93/64/09, specimen no. p19). fig. 15. Subbotina linaperta Finlay (Krzesławice 11/38a/09, specimen no. 3). Scale bars $100 \mu \mathrm{m}$. 
opportunistic forms recolonizing the sea floor (Kitazato, 1995; Nagy et al., 2010; Waśkowska, 2011a). These are assemblages of foraminifera characteristic of the first stages of rebuilding the structure of the association after the crisis, i.e. the survival phase. They can exist for a short time (Waśkowska, 2011a) or last for a long interval during adverse conditions (Kaiho, 1999). In the early Eocene flysch deposits assemblages of this type are common, where there are mass occurrences of stunted Glomospira.

\section{Bathymetry}

Small-sized Trochammina assemblages developed close to the foraminifera lysocline and local carbonate compensation depth (CCD). Such a bathymetry is indicated by the assemblage structure, dominated by agglutinated foraminifera. Calcareous forms belonging to plankton and benthos are represented irregularly in the assemblages, as a minor component. The surfaces of their tests bear distinctive signs of corrosion, which is the result of partial or complete dissolution, resulting in internal moulds. There are probably a few forms that have been preserved and have not been destroyed at depths corresponding to the CCD.

\section{CONCLUSIONS}

Assemblages with numerous small-sized Trochammina appeared in the Eocene in the Silesian Basin, where they are characteristic of the lower part of the Hieroglyphic beds. In Krzesławice they occur within a $50 \mathrm{~m}$ thickness of mudstone shales, and in Janoska they are present within a sequence of more than $100 \mathrm{~m}$ thick developed as grey mudstones with relatively large amounts of muscovite, pyrite and low amounts of TOC.In the studied deposits foraminiferal assemblages are observed that are dominated by opportunistic forms of the genus Trochammina, which frequently represents more than $70 \%$ of all foraminifera. Their characteristic features are the presence of numerous dwarfed forms, low taxonomic diversity, association with cosmopolitan forms, i.e. Bathysiphon, Recurvoides, Paratrochamminoides and Trochamminoides, and strong dominance of epifaunal and shallow mobile infaunal morphogroups. These assemblages are developed in deep-water environments, close to the local CCD.

The late Ypresian age of the Trochammina biofacies was assessed on the basis of the presence of index taxa for this interval, i.e. Saccamminoides carpathicus Geroch, and occasional cooccurring planktonic foraminifera. The Trochammina biofacies developed in the Silesian Basin after the Paleocene-Eocene benthic foraminiferal extinction (associated with the PETM), as a recolonizing assemblage. The biofacies remained stable during the early Eocene, in conditions that restricted the development of more complex foraminiferal assemblages.

\section{ACKNOWLEDGEMENTS}

The author is indebted to M. Cieszkowski (Jagiellonian University) for helpful discussions and R. Chodyń (Jagiellonian University), S. Bębenek (AGH University of Science and Technology) and R. Stadnik (AGH) for help with fieldwork. Thanks are extended to T. Wójcik for help with sample preparation. The scanning electron micrographs were made in the Faculty of Materials Science and Ceramic UST. Thanks go to L. Alegret (University of Zaragoza) and to the anonymous reviewers for their constructive comments on the manuscript. M. Kaminski (KFUPM) is thanked for correcting a version of the manuscript. This research received support from the AGH University of Science and Technology grant No 11.11. 140. 173.
Manuscript received 28 May 2013

Manuscript accepted 8 January 2014

Scientific Editing by Laia Alegret

\section{REFERENCES}

Alegret, L., Ortiz, S., Arenillas, I. \& Molina, E. 2010. What happens when the ocean is overheated? The foraminiferal response across the Paleocene-Eocene Thermal Maximum at the Alamedilla section (Spain). Geological Society of America Bulletin, 122: 1616-1624.

Alve, E. 1999. Colonization of new habitats by benthic foraminifera: A review. Earth-Science Reviews, 46: 167-185.

Arreguin-Rodriguez, G.J., Alegret, L. \& Ortiz, S. 2013. Glomospira Acme during the Paleocene-Eocene Thermal Maximum: Response to $\mathrm{CaCo3}$ dissolution or to ecological forces? Journal of Foraminiferal Research, 43: 40-54.

Bąk, K. 2004. Deep-water agglutinated foraminiferal changes across the Cretaceous/Tertiary and Paleocene/Eocene transitions in the deep flysch environment; eastern Outer Carpathians (Bieszczady Mts, Poland). In Bubik, M. \& Kaminski, M.A. (Eds), Proceedings of the Sixth International Workshop on Agglutinated Foraminifera. Grzybowski Foundation, Special Publication, 8: 1-56.

Bąk, M. \& Barwicz-Piskorz, W. 2005. Stratigraphical and ecological significance of Early Eocene radiolarians from the Subsilesian Series, Polish Flysch Carpathians. Annales Societatis Geologorum Poloniae, 75: 139-115.

Bąk, K., Bąk, M., Geroch, S. \& Manecki, M. 1997. Biostratigraphy and paleoenvironmental analysis of benthic foraminifera and radiolarians in Paleogene variegated shales in the Skole unit, Polish Flysch Carpathians. Annales Societatis Geologorum Poloniae, 67: 135-154.

Barbosa, C.F., Scott, D., Seoane, J.C.S. \& Turcq, B.J. 2005. Foraminiferal zonations as base lines for Quaternary sea-level fluctuations in SouthSoutheast Brazilian Mangroves and marshes. Journal for Foraminiferal Research, 35: 22-43.

Benhard, J.M. 1986. Characteristic assemblages and morphologies of benthic foraminifera from anoxic, organic-rich deposits; Jurassic through Holocene. Journal of Foraminiferal Research, 16: 207-215.

Boersma, A., Premoli Silva, I. \& Shackleton, N.J. 1987. Atlantic Eocene planktonic foraminiferal paleohydrographic indicators and stable isotope paleoceanography. Paleoceanography, 2: 287-331.

Bubik, M. 1994. Bioevents at the Paleocene/Eocene boundary in flysch sediments of the Biele Karpaty Unit (West Carpathians, Czech Republic). Geolines, 1: 3-5.

Bubik, M. 1995a. Occurrence of the genus Eratidus (Foraminifera) in the Eocene of the Moravian flysch. Geologické výzkumy na Moravě a ve Slezsku v roce 1994, Brno, 2: 17-18.

Bubik, M. 1995b. Cretaceous to Paleogene agglutinated foraminifera of the Biele Karpaty unit (West Carpathians, Czech Republic). In Kaminski, M.A., Geroch, S. \& Gasinski, M.A. (Eds), Proceedings of the Fourth International Workshop on Agglutinated Foraminifera. Grzybowski Foundation, Special Publication, 3: 71-116.

Bubik, M. 2006. Results of mapping and stratigraphic research in the Silesian Unit on the Horní Bečva map sheet. Zprávy o geologických výzkumech v roce 2006: 9-14.

Bubik, M., Bąk, M. \& Svabenicka, L. 1999. Biostratigraphy of the Maastrichtian to Paleocene distal flysch sediments of the Raca Unit in the Uzgrun section (Magura Group of nappes, Czech Republic). Geologica Carpathica, 50: 33-48.

Burtan, J. 1974. Detailed Geological Map of Poland, 1: 50 000, Mszana Dolna Sheet. Wydawnictwa Geologiczne, Warszawa.

Burtan, J. 1978. Explanations Detailed Geological Map of Poland, 1: 50 000, Mszana Dolna Sheet. Wydawnictwa Geologiczne, Warszawa, 70pp.

Burtan, J., Sokołowski, S., Sikora, W. \& Żytko, K. 1956. Detailed Geological Map of Poland 1: 50 000, Milówka Sheet. Wydawnictwa Geologiczne, Warszawa. 
Chodyń, R. \& Waśkowska-Oliwa, A. 2006. Lithostratigraphy and biostratigraphy of the Paleocene-Early Oligocene flysch sediments in the western part of the Szczyrzyc Synklinorium, Silesian Nappe (Polish Outer Carpathians). In Sudar, M., Ercegovac, M. \& Grubić, A. (Eds), Proceedings XVIIIth Congress of the Carpathian Balkan Geological Association. Scientific Annals of the School of Geology, Aristole University of Thessaloniki, Belgrade, Serbia, Special Volume, 100: 57-60.

Cieszkowski, M., Leśniak, T., Środoń, J. \& Waśkowska-Oliwa, A. 2006. Bentonitized tuffites in the Lower Eocene deposits of the Subsilesian Unit (Wester Outer Carpathians, Poland). Annales Socetatis Geologorum Poloniae, 76: 197-214.

Cieszkowski, M., Waśkowska, A. \& Kaminski, M.A. 2011. Deep-water agglutinated foraminifera in Paleogene hemipelagic sediments of the Magura Basin in the Sucha Beskidzka area - variegated shales of the Labowa Shale Formation. In Bąk, M., Kaminski, M.A. \& Waśkowska, A. (Eds), Integrating Microfossil Records from the Oceans and Epicontinental Seas. Grzybowski Foundation, Special Publication, 17: 53-63.

Coccioni, R. \& Galeotti, S. 1994. KT boundary extinction: Geologically instantaneous or gradual event? Evidence from deep-sea benthic foraminifera. Geology, 22: 779-782.

Corliss, B.H. \& Honjo, S. 1981. Dissolution of deep-sea benthonic foraminifera. Micropaleontology, 27: 365-378.

Doktor, M., Golonka, J., Waśkowska, A. \& Słomka, T. 2010. The best geotouristic objects of the Silesian Unit, Outer Flysch Carpathians in the vicinity of Kraków, Poland. Scientific Annals, School of Geology, Aristole University of Thessaloniki, 100: 459-466.

Funnell, B.M. 1967. Foraminifera and Radiolaria as depth indicators in the marine environment. Marine Geology, 5: 333-347.

Galeotti, S., Kaminski, M.A., Coccioni, R. \& Speijer, R. 2004. High resolution Deep Water Agglutinated and Calcareous Hyaline foraminiferal record across the Paleocene/Eocene transition in the Contessa Road Section (central Italy). In Bubik, M. \& Kaminski, M.A. (Eds), Proceedings of the Sixth International Workshop on Agglutinated Foraminifera. Grzybowski Foundation, Special Publication, 8: 83-103.

Geroch, S. 1959. Stratigraphic significance of arenaceous foraminifera in the Carpathian flysch. Paläontologische Zeitschift, 33: 113-122.

Geroch, S. 1960. Microfaunal assemblages from the Cretaceous and Palaeogene Silesian unit in the Beskid Slaski Mts. Western Carpathians. Biuletyn Instytutu Geologicznego, 153: 1-138.

Geroch, S. \& Koszarski, L. 1988. Agglutinated foraminiferal stratigraphy of the Silesian flysch trough. Abhandlungen der Geologischen Bundesanstalt, 41: 73-79.

Geroch, S. \& Nowak, W. 1984. Proposal of zonation for the late Tithonian-late Eocene, based upon arenaceous Foraminifera from the Outer Carpathians, Poland. In Benthos '83, 2ndInternational Symposium on Benthic Foraminifera. Pau, 225-239.

Geroch, S., Jednorowska, A., Książkiewicz, M. \& Liszkowa, J. 1967. Stratigraphy based upon microfauna in the Western Polish Carpathians. Biuletyn Instytutu Geologicznego, 211: 185-282.

Geslin, E., Heinz, P. \& Hemleben, C. 2004. Behaviour of Bathysiphon $\mathrm{sp}$. and Siphonammina bertholdii $\mathrm{n}$. gen n.sp. under controlled oxygen conditions in the laboratory. implication for bioturbation. In Bubik, M. \& Kaminski, M.A. (Eds), Proceedings of the Sixth International Workshop on Agglutinated Foraminifera. Grzybowski Foundation, Special Publication, 8: 1105-1118.

Golonka, J. 2011. Evolution of the Outer Carpathian Basins. In Bąk, M., Kaminski, M.A. \& Waśkowska, A. (Eds), Integrating Microfossil Records from the Oceans and Epicontinental Seas. Grzybowski Foundation, Special Publication, 17: 3-14.

Golonka, J. \& Waśkowska-Oliwa, A. 2007. Stratigraphy of the Polish Flysch Carpathians between Bielsko-Biała and Nowy Targ. Kwartalnik AGH Geologia, 33: 5-28.
Golonka, J., Gahagan, L., Krobicki, M., Marko, F., Oszczypko, N. \& Slaczka, A. 2006. Plate Tectonic Evolution and Paleogeography of the Circum-Carpathian Region. In: Golonka, J. \& Picha, F. (Eds), The Carpathians and their Foreland. Geology and Hydrocarbon Resources. American Association of Petroleum Geologists, Memoir, 84: 11-46.

Golonka, J., Krobicki, M., Waśkowska-Oliwa, A., Vašíček, Z. \& Skupien, P. 2008. Main paleogeographical elements of the West Outer Carpathians during Late Jurassic and Early. Kwartalnik AGH Geologia, 34: 61-72.

Golonka, J., Pietsch, K. \& Marzec, P. 2011. Structure and plate tectonic evolution of the northern Outer Carpathians. In Closson, D. (Ed.), Tectonics. Intech, Rijeka, Croatia, 65-92.

Gooday, A.J., Levin, L.A., Thomas, C.L. \& Hecker, B. 1992. The distribution and ecology of Bathysiphon filiformis Sars and B. major de Folin (Protista, Foraminiferida) on the continental slope off North Carolina. Journal of Foraminiferal Research, 22: 129-146.

Gooday, A.J., Pond, D.W. \& Bowser, S.S. 2002. Ecology and nutrition of the large agglutinated foraminiferan Bathysiphon capillare in the bathyal NE Atlantic distribution within the sediment profile and lipid biomarker composition. Marine Ecology Progress Series, 245: 69-82.

Hanzlikova, E. \& Pesl, V. 1964. Prispevek k poznani facialniho vyvoje spodniho Odilu paleogenu racanske serie magurskeho flyse. Vestnik Ustredniho Ustavu Geologickeho, 39: 419-428.

Harries, P., Kauffman, E. \& Hansen, A. 1996. Models for biotic survival following mass extinction. In Hart, M.B. (Ed.), Biotic recovery from Mass Extinction Events. Geological Society, London, Special Publications, 102: 41-60.

Hawkes, A.D., Horton, B.P., Nelson, A.R. \& Hill, D.F.D. 2010. The application of intertidal foraminifera to reconstruct coastal subsidence during the giant Cascadia earthquake of AD 1700 in Oregon, USA. Quaternary International, 221: 116-140.

Hollis, C., Jenns, E., Begbie, M. \& Pullin, A. 1995. Benthic foraminifera and other microbiotic remains in Waimamaku river estuary, West Coast, Northland. Tane, 35: 195-2005.

Hromic, T., Camblor, M. \& Quezada, L. 2012. Textularids foraminifers from recent shallow sediments of the Antarctic Peninsula and other relationship with Southern Southamerican Region. Annales del Instituto da la Patagonia, 40: 125-138.

Jones, G.D. 1988. A paleoecological model of Late Paleocene "flysch-type" agglutinated foraminifera using the paleoslope transect approach, Viking Graben, North Sea. Abhandlungen der Geologischen Bundesanstalt, 41: 143-153.

Jones, R.W. \& Charnock, M.A. 1985. Morphogroups" of agglutinated Foraminifera, their life positions and feeding habits and potential applicability in (paleo)ecological studies. Revue de Paléobiologie, 4: 311-320.

Jurkiewicz, H. 1967. Otwornice paleogenu podmenilitowego polskich Karpat środkowych. Biuletyn Instytutu Geologicznego, 210: 5-128.

Kaiho, K. 1999. Evolution in the test size of deep-sea benthic foraminifera during the past $120 \mathrm{~m} . \mathrm{y}$. Marine Micropaleontology, 37: 53-65.

Kaiho, K., Morgans, E.G. \& Okada, H. 1993. Faunal turnover of intermediate-water foraminifera during the Paleogene in New Zeland. Marine Micropaleontology, 23: 51-86.

Kaiho, K., Arinobu, T., Ishiwatari, R. et al. 1996. Latest Paleocene benthic foraminiferal extinction and enviromental changes at Tawanui, New Zealand. Paleoceanography, 11: 447-465.

Kaminski, M.A. 2005. The utility of deep-water agglutinated foraminifera for correlating Eocene to Oligocene abyssal sediments in the North Atlantic \& Western Tethys. Studia Geologica Polonica, 124: 325-340.

Kaminski, M.A. \& Gradstein, F.M. 2005. Atlas of Paleogene Cosmopolitan Deep-Water Agglutinated Foraminifera. Grzybowski Foundation, Special Publication, 10, 1-547.

Kaminski, M.A., Gradstein, F.M. \& Berggren, W.A. 1989. Paleogene benthic foraminifer biostratigraphy and paleoecology at Site 647, Southern 
Labrador Sea. Proceedings of Ocean Drilling Program, Scientific Results, 105. Ocean Drilling Program, College Station, TX, 705-729.

Kaminski, M.A., Kuhnt, W. \& Radley, J.D. 1996. Palaeocene-Eocene deep water agglutinated foraminifera from the Numidian Flysch (Rif, Northern Marocco): Their significance for the palaeoceanography of the Gibraltar gateway. Journal of Micropaleontology, 15: 1-19.

Kaminski, M.A., Kuhnt, W. \& Moullade, M. 1999. The evolution and paleobiogeography of abyssal agglutinated foraminifera since the Early Cretaceous: A tale of four faunas. Neues Jahrbuch für Geologie und Paläontologie Abhandlungen, 212: 401-439.

Kaminski, M.A., Cetean, C.G., Henderson, A. \& Filipescu, S. 2007. On the Cretaceous occurrences of Ammogloborotalia Zheng, 2001 (Foraminifera). Studia Universitatis Bables-Bolyai, Geologia, 52: 67-71.

Kender, S., Kaminski, M.A. \& Cieszkowski, M. 2005. Foraminifera from the Eocene Variegated Shales near Barwinek (Magura Unit, Outer Carpathians), the type locality of Noth (1912) Revisited. Annales Societatis Geologorum Poloniae, 75: 249-271.

Kender, S., Kaminski, M.A. \& Jones, R.W. 2008. Early to Middle Miocene Foraminifera from the deep-sea Congo Fan, offshore Angola. Micropaleontology, 55: 477-568.

Kennett, J.P. \& Stott, L.D. 1991. Abrupt deep-sea warming, paleoceanographic changes and benthic extinctions at the end of the Palaeocene. Nature, 353: 225-229.

Kitazato, H. 1995. Recolonization by deep-sea benthic foraminifera: Possible substrate preferences. Marine Micropaleontology, 26: 65-74.

Kuhnt, W. \& Collins, E.S. 1996. Cretaceous to Paleogene benthic foraminifers from the Iberia Abyssal Plain. In Whitmarsh, R.B., Sawyer, D.S., Klaus, A. \& Masson, D.G. (Eds), Proceedings of the Ocean Drilling Program, Scientific Results, 149: 203-216.

Kuhnt, W. \& Kaminski, M.A. 1990. Paleoecology of Late Cretaceous to Paleocene deep-water agglutinated foraminifera from the North Atlantic and Western Tethys. In Hemleben, C., Kaminski, M.A., Kuhnt, W. \& Scott, D.B. (Eds), Paleoecology, Biostratigraphy, Paleoceanography and Taxonomy of Agglutinated Foraminifera. Kluwer, Dordrecht, 433-505.

Kuhnt, W., Moullade, M. \& Kaminski, M.A. 1996. Ecological structuring and evolution of deep sea agglutinated foraminifera - a review. Revue de Micropaléontologie, 39: 271-281.

Małecki, J. 1973. Bathysiphons from the Eocene of the Carpathian Flysch, Poland. Acta Paleontologica Polonica, 18: 163-174.

Malinowska, L. 1984. Budowa Geologiczna Polski, Tom III. Atlas skamieniatości przewodnich i charakterystycznych, Mezozoik. Kreda. Wydawnictwa Geologiczne, Warszawa, 579pp.

Mancin, N. 2001. Agglutinated foraminifera from the Epiligurian succession (Middle Eocene/Lower Miocene, Northern Apennines, Italy): Scanning electron microscopic characterization and paleoenvironmental implications. Journal of Foraminiferal Research, 31: 294-308.

McGann, A., Grossman, E.E., Takesue, R.K., Penttila, D., Walsh, J.P. \& Corbett, R. 2012. Arrival and expansion of the invasive Trochammina hadai Uchio in Padilla Bay, Washington. Northwest Since, 86: 9-26.

Miller, K.G., Janesek, T.R., Katz, M.E. \& Keil, D.J. 1987. Abyssal circulation and benthic foraminiferal changes near Paleocene/Eocene boundary. Paleaoceanography, 2: 741-761.

Miller, K.G. \& Lohmann, G.P. 1982. Environmental distribution of Recent benthic foraminifera on the northeast United States continental slope. Geological Society of America Bulletin, 93: 200-206.

Morgiel, J. \& Olszewska, B. 1981. Biostratigraphy of the Polish External Carpathians based on agglutinated foraminifera. Micropaleontology, 27: $1-30$.

Morgiel, J. \& Olszewska, B. 1982. Uniformity of the Tethyan faunas from Cretaceous and Paleogene as shown by foraminifera from Marocco and Polish Flysch Carpathians. Micropaleontology, 27: 1-30.

Morgiel, J. \& Szymakowska, F. 1978. Stratygrafia paleocenu i eocenu jednostki skolskiej. Biuletyn Instytutu Geologicznego, 19: 39-71.

Murray, J.W. 1991. Ecology and Palaeoecology of Benthic Foraminifera. Longman Scientific and Technical, England, 397pp.
Murray, J.W., Alve, E. \& Jones, R.W. 2011. A new look at modern agglutinated benthic foraminiferal morphogroups: Their value in palaeoecological interpretation. Palaeogeography, Palaeoclimatology, Palaeoecology, 309: 229-241.

Nagy, J., Løfaldli, M.L. \& Backstrom, S.A. 1988. Aspects of foraminiferal distribution and depositional conditions in Middle Jurassic to Early Cretaceous shales in Eastern Spitsbergen. Abhandlungen der Geologischen Bundesanstalt, 41: 287-300.

Nagy, J., Gradstein, F.M., Kaminski, M.A. \& Holborn, A.E.L. 1995. Foraminiferal morphogroups, paleoenvironments and new taxa from Jurassic and Cretaceous strata of Thakkhola, Nepal. In Kaminski, M.A., Geroch, S. \& Gasiński, M.A. (Eds), Proceedings of the Fourth International Workshop on Agglutinated Foraminifera. Grzybowski Foundation, Special Publication, 3: 181-209.

Nagy, J., Hess, S. \& Alve, E. 2010. Environmental significance of foraminiferal assemblages dominated by small-sized Ammodiscus and Trochammina in Triassic and Jurassic delta-influenced deposits. EarthScience Reviews, 99: 31-49.

Olszewska, B. 1981. Paleoecological characteristics of small foraminifers from the Lower Eocene claystones with clinoptilolite from the Polish part of Outer Carpathians (in Polish with English summary). Biuletyn Instytutu Geologicznego, 331: 69-82.

Olszewska, B. 1984. A paleoecological interpretation of the Cretaceous and Paleogene foraminifers of the Polish Outer Carpathians (in Polish with English summary). Biuletyn Instytutu Geologicznego, 346: 7-62.

Olszewska, B. 1997. Foraminiferal biostratigraphy of the Polish Outer Carpathians: a record of basin geohistory. Annales Societatis Geologorum Poloniae, 67: 325-337.

Olszewska, B., Odrzywolska-Bieńkowa, E., Giel, M.D., Pożaryska, K. \& Szczechura, K. 1996. Foraminiferida Eichwald, 1830. In Limanowska, L. \& Piwocki, M. (Eds), Geology of Poland. Atlas of Characteristic Fossils. Cenozoic. Tertiary. Paleogene. 3, Part 3a. Państwowy Instytut Geologiczny, 45-215.

Ortiz, S., Alegret, L., Payros, A., Orue-Etxebarria, X., Apellaniz, E. \& Molina, E. 2011. Distribution patterns of benthic foraminifera across the Ypresian-Lutetian Gorrondatxe section, Northern Spain: response to sedimentary disturbance. Marine Micropaleontology, 78: $1-13$.

Oszczypko, N., Malata, E., Bąk, K., Kędzierski, M. \& Oszczypko-Clowes, M. 2005. Lithostratigraphy, biostratigraphy and palaeoenvironment of the Upper Albian-Lower/Middle Eocene flysch deposits in the Beskid Wyspowy and Gorce Ranges; Polish Outer Carpathians, Magura Nappe; Bystrica \& Rača subunits. Annales Societatis Geologorum Poloniae, 75 : $27-69$.

Pak, D.K. \& Miller, K.G. 1992. Paleocene to Eocene benthic foraminiferal isotopes and assemblages: implications for deep-water circulation. Paleaoceanography, 7: 405-422.

Pardo, A., Keller, G. \& Oberhänsli, H. 1999. Paleoecologic and paleoceanographic evolution of the Tethyan realm during the PaleoceneEocene transition. Journal of Foraminiferal Research, 29: 37-57.

Pearson, P.N., Olsson, R.K., Huber, B.T., Hemleben, C. \& Berggren, W.A. 2006. Atlas of Eocene planktonic foraminifera. Cushman Foundation for Foraminifera Research, Special Publication, 41: 1-513.

Peryt, D., Lahodynsky, R. \& Durakiewicz, T. 1997. Deep-water agglutinated foraminiferal changes and stable isotope profiles across the Cretaceous-Paleogene boundary in the Rotwandgraben section, Eastern Alps (Austria). Palaeoegography, Palaeoclimatology, Palaeoecology, 132: 287-307.

Rasmussen, J.A., Nøhr-Hansen, H. \& Sheldon, E. 2003. Palaeoecology and palaeoenvironments of the Lower Palaeogene succession, offshore West Greenland. Marine and Petroleum Geology, 20: 1043-1073.

Schnitker, D. \& Tjalsma, L.R.C. 1980. New genera and species of benthic foraminifers from Paleocene and Eocene deep water deposits. Journal of Foraminiferal Research, 10: 235-241. 
Schönfeld, J. 2002. A new benthic foraminiferal proxy for near-bottom current velocities in the Gulf of Cadiz, northeastern Atlantic Ocean. Deep-Sea Research I, 49: 1853-1875.

Scott, D. \& Medioli, F.S. 1980. Quantitative studies of marsh foraminiferal distributions in Nova Scotia and comparison with those in other parts of the world: implications for sea level studies. Special Publication of the Cushman Foundation for Foraminiferal Research, 17: 1-58.

Scott, D., Gradstein, F., Schaffer, C., Miller, A. \& Williamson, M.. 1983. The recent as a key to the past: does it apply to agglutinated foraminiferal assemblages? In Verdenius, J.G. et al. (Eds), Proceedings of First Workshop on Arenaceous Foraminifera. Continental Shelf Institute, Norway, 108: 147- 157.

Setoyama, E., Kaminski, M.A. \& Tyszka, J. 2011. The Late CretaceousEarly Paleocene palaeobathymetric trends in the southwestern Barents Sea - Palaeoenvironmental implications of benthic foraminiferal assemblage analysis. Palaeogeography, Palaeoclimatology, Palaeoecology, 307: 44-58.

Smith, A.J. \& Gallagher, S.J. 2003. The Recent foraminifera and facies of the Bass Canyon: a temperate submarine canyon in Gippsland, Australia. Journal of Micropaleontology, 22: 63-83.

Thomas, E. 1998. The biogeography of the Late Paleocene benthic foraminiferal extinction. In Aubry, M.P., Lucas, S.G. \& Berggren, W.A. (Eds), Late Paleocene-Early Eocene biotic and climatic events in the marinae and terrestial records. Columbia University Press, New York, 214-243.

Thomas, E. \& Shackleton, N.J. 1996. The Paleocene-Eocene benthic foraminiferal extinction and stable anomalies. In Knox, R.W. (Ed.), Correlation of the Early Paleogene in Northwest Europe. Geological Society of America, Special Publications, 101: 401-411.

Tjalsma, R.C. \& Lohmann, G.P. 1983. Paleoocene-Eocene bathyal and abyssal benthic foraminifera from the Atlantic Ocean. Micropaleontology, Special Publication, 4: 1-90.

van Morkhoven, F.P.C.M., Berggren, W.A. \& Edwards, A. 1986. Cenozoik cosmopolitan deep-water benthic foraminifera. BCRE-RelfAquitain, 267pp.
Waśkowska, A. 2011a. Response of Early Eocene deep-water benthic foraminifera to volcanic ash falls in the Polish Outer Carpathians. Palaeogeography, Palaeoclimatology, Palaeoecology, 305: 50-64.

Waśkowska, A. 2011b. The Early Eocene Saccamminoides carpathicus Assemblage in the Outer Flysch Carpathians. In Kaminski, M.A. \& Filipescu, S. (Eds), Proceedings of the Eight International Workshop on Agglutinated Foraminifera. Grzybowski Foundation, Special Publication, 16: 331-341.

Waśkowska, A. 2012. Monospecific foraminiferal assemblages with Trochammina in Early Eocene Carpathian deposits (Silesian unit, Polish Outer Carpathians). In Hladilova, S., Dolakova, N. \& Dostal, O. (Eds) Sbornik Prispevku 13th Czech-Slovak-Polish Paleontological Conference. Mendel Museum, Brono, 70.

Waśkowska-Oliwa, A. 2000. Interpretacja biostratygraficzna i paleoekologiczna zespołów otwornic aglutynujacych z paleoceńsko-środkowo eoeńskich osadów płaszczowiny magurskiej w rejonie Suchej Beskidzkiej (Karpaty fliszowe). Przeglad Geologiczny, 48: 331-336.

Waśkowska-Oliwa, A. 2005. Foraminiferal paleodepth indicators from the lower Palaeogene deposits of the Subsilesian Unit (Polish Outer Carpathians). Studia Geologica Polonica, 124, 297-324.

Waśkowska-Oliwa, A. 2008. The Paleocene assemblages of agglutinated foraminifera from deep-water basin sediments of the Carpathians (Subsilesian Unit, Poland) - biostratigraphical remarks. In Kaminski, M.A. \& Coccioni, R. (Eds), Proceedings of the Seventh International Workshop on Agglutinated Foraminifera. Grzybowski Foundation, Special Publication, 13: 227-265.

Waśkowska-Oliwa, A. \& Leśniak, T. 2003. Biostratigratigraphy and palaeoecology of Early Palaeogene deep water foraminiferal assemblages from the Subsilesian Unit in the Żywiec tectonic window (Polish Outer Carpathians). Bulletin of the Polish Academy of Sciences, 51: $11-27$.

Waśkowska-Oliwa, A., Cieszkowski, M., Stadnik, R. \& Chodyń, R. 2008. Warstwy hieroglifowe serii śląskiej na SE od Dobczyc, zachodnie Karpaty zewnętrzne. In Haczewski, G. (Ed.), Abstrakty, Pierwszy Kongres Geologiczny. Polskie Towarzystwo Geologiczne: 127. 
